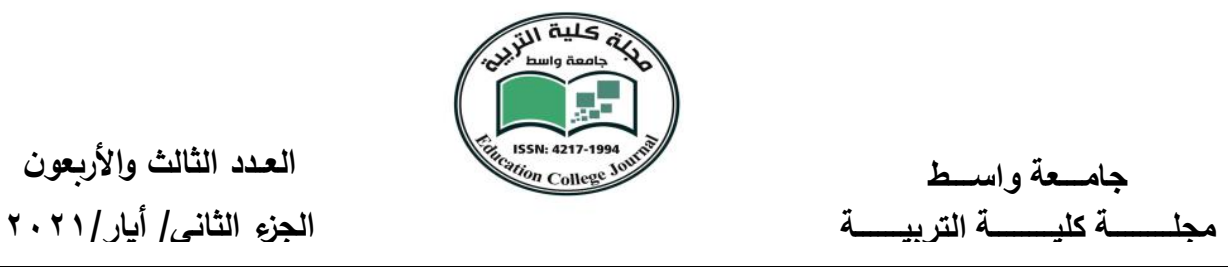

\title{
الرسائل الحربيّة في وقعة صفين مقاربة تداوليّة
}

م.د. أحمد حسين حيال

مديرية تربية بغداد / الرصافة الثالثة

ah1975.h.h@gmail.com

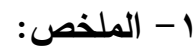

نحاول في بحثنا هذا كثف القيم التداولية التي تضمنتها الرسائل الحربيّة التي جمعها ابن مزاحم المنقري (ت T آTه) في مدونته (وقعة صفين)، والتي جمع فيها ما استطاع من مراسلات

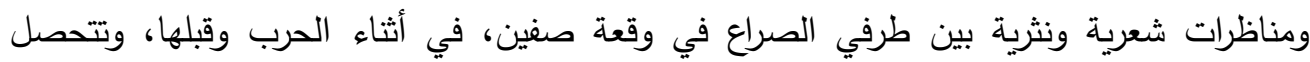

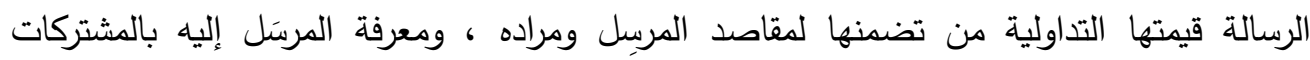

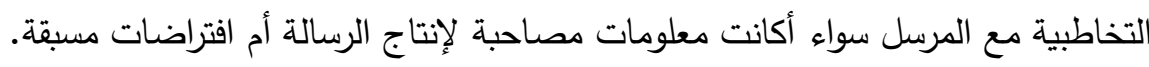
الكلمات المفتاحيّة: الخطاب الحربي، الرسائل، الإخبار ، الاستدلال.

\section{Abstract}

In this research, we try to uncover the deliberative values contained in the war messages collected by Ibn Muzahem al-Munqari (T 212H) in his blog (Sifin Post), in which he collected all his correspondence, poetry and prose during and before the war The message receives its deliberative value from its contents for the purposes of the sender and its intended purpose, and the recipient's knowledge of the communication participants with the sender whether it is information accompanying the production of the message or presuppositions.

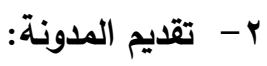

تُعد مدونة (وقعة صفين)، من أوائل المدونات التأريخيّة التي عُنيت بتدوين وقائع حرب صفين

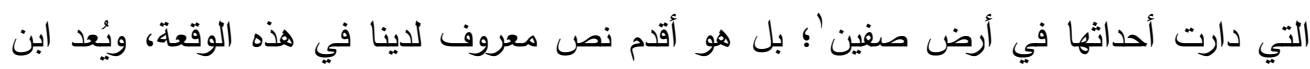

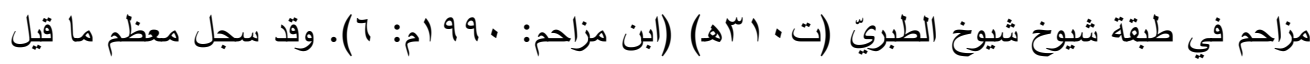

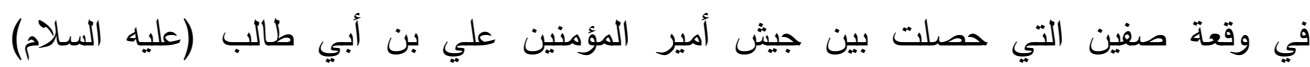

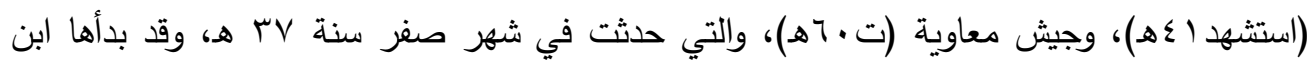

$$
\text { ' صفين موضع بقرب الرقة على شاطىء الفرات من الجانب الغربي بين الرَقة وبالس(الحموي: ب99 ام: } 0 \text { / 19). }
$$


العدد الثالث والأربعون

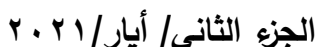

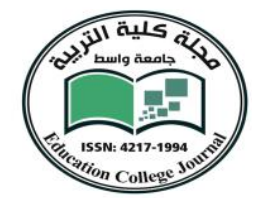

مزاحم بداية دراميّة ناجحة؛ إذ ذكر في الرواية الأولى وصول الإمام علي بن أبي طالب (عليه

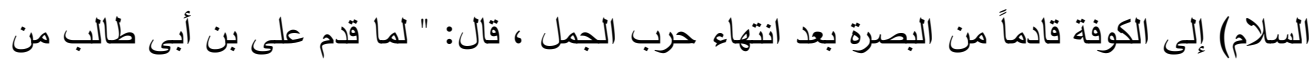
البصرة إلى الكوفة يوم الاثثين لثنتى عشرة ليلة مضت من رجب سنة ست وثلاثين، وقد أعز الله نصره وأظهره على عدوه، ومعه أشراف الناس وأهل البصرة، استقبله أهل الكوفة وفيهم قراؤهم وأشرافهم،

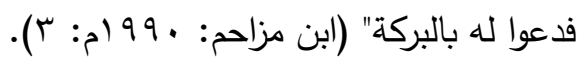
وهذه البداية إيذاناً منه أن كل ما سيكون بعدها خاص بوقعة صفين، وقد دل على هذا ما نقله من أبيات شعر لبشر بن منقذ (ت.0ه) المعروف بالأعور الثني الذي يقول فيها (ديوان الأعور

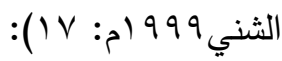

قل لهـا الإمام قد خبت الحـر ب وتمت بذلك النعماء

وفرغنا من حرب من نقض العه د وبالثام حية صماء

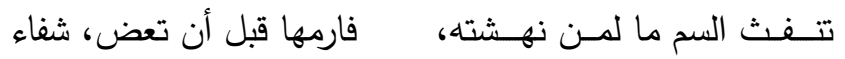

فهذه الدعوة من أنصار الإمام لمهاجمة معاوية وطرده من كرسي الثام لم تكن اعتباطاً؛ وإنما سيقت لوجود قرائن عقليّة مترابطة وأدلة بيّنة واضحة على أن معاوية قد دق طبول الحرب وأذِن لها،

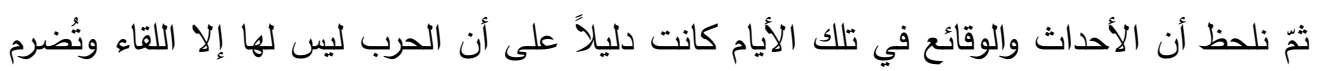
نارها، ولاسيما أنّ شراراتها قد بدأت حينما أرسل أمير المؤمنين رسالة إلى معاوية يأمره فيها بترك ولاية الثام والتحي عن إمارتها، وممّا جاء فيها قوله: "أما بعد فإن بيعتي بالمدينة لزمتك وأنت بالثام ،

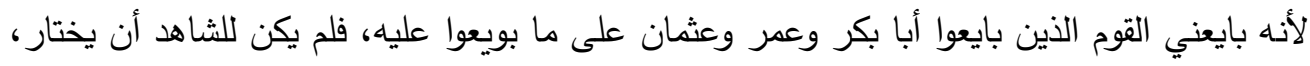
ولا للغائب أن يرد ... فإن خرج من أمرهم خارج بطعن أو رغبة ردوه إلى ما خرج منه، فإن أبى قاتلوه على اتباعه غير سبيل المؤمنين ... فإن أحب الأمور إليَّ فيك العافية، إلا أن تتعرض للبلاء. فإن تعرضت له قاتلتك واستعنت الله عليك" (ابن مزاحم: •99 1: 99)، هذا الأمر صار إعلاناً رسمياً

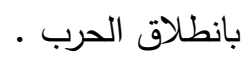

أخذت المقدمة الكاشفة لمقامات المعركة مساحة كافية لاستعراض البيئة التي مهدت للوقعة والظروف التي سبقت اللقاء الدامي بين الجيشين، فكان الغرض من هذا التقديم هو تبيان البيئة الاجتماعيّة والسياسية التي سبقت حرب صفين، والمقامات التي أنتجتها، وهي بيئة سيفاد منها قارئ الكتاب لمعرفة كثير من أحداث الوقعة، وهي كذا مفيدة للمنقري في إضفاء سمة المنهجية على 
العدد الثالث والأربعون

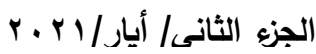

r- عنوان الوقعة:

تكتسب الأحداث والوقائع التاريخيّة تسمياتها من الظروف التي تضمنتها، فعام الفيل مثلاً

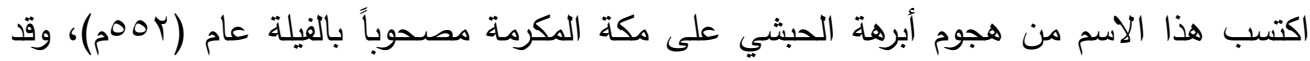

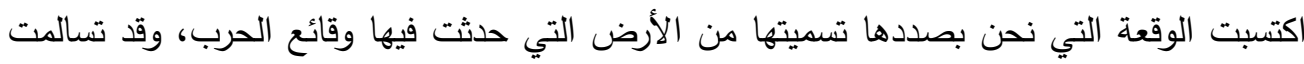

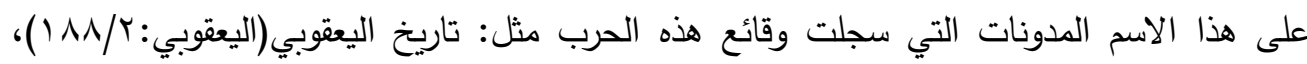

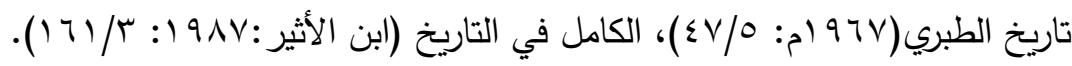

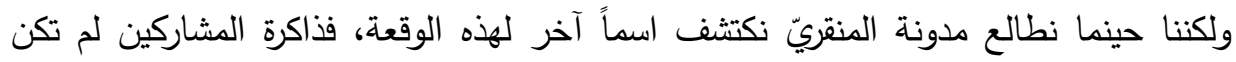

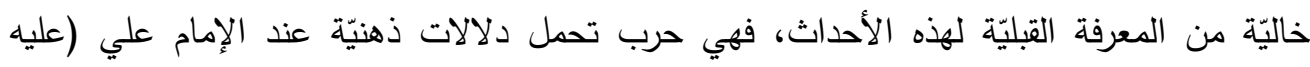

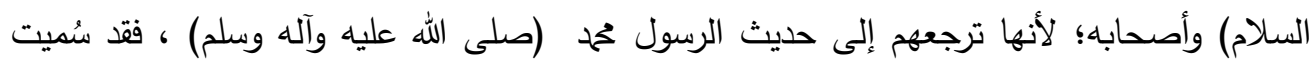

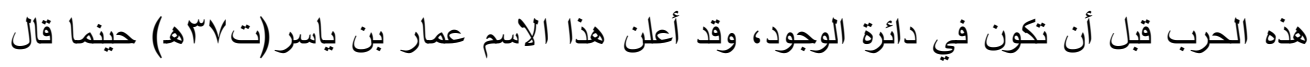

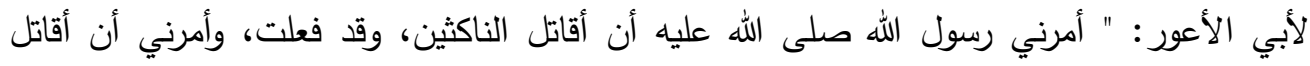

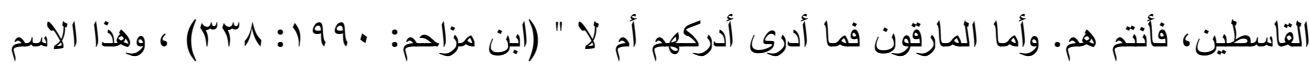

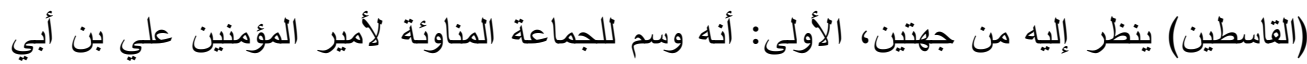
طالب (عليه السلام) ، والأخرى: أنه وسم أطلق من الرسول (صلى الله عليه وآله وسلم) ولا يمكن لإنه

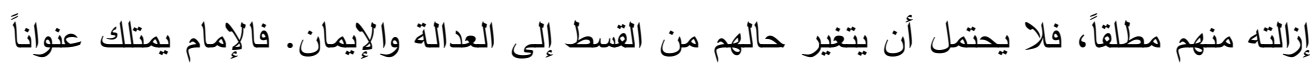

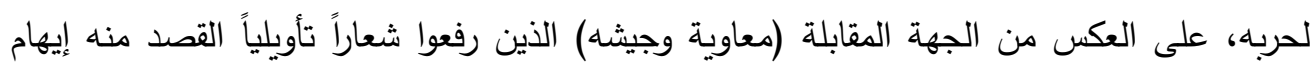

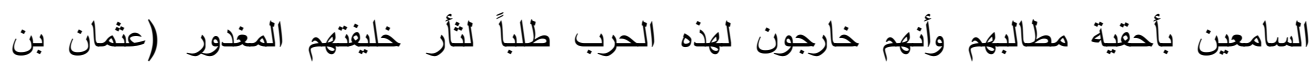

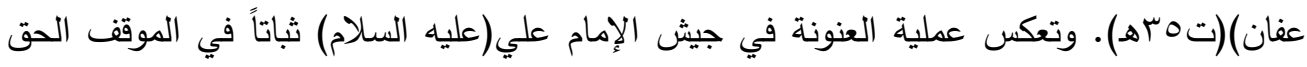

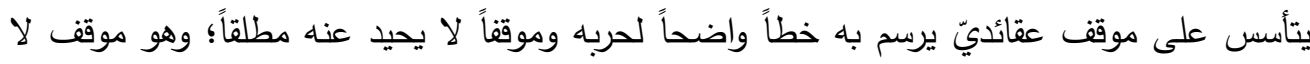

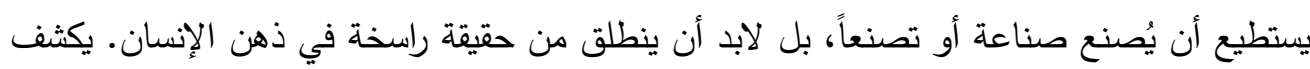

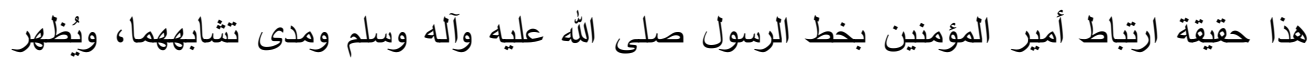

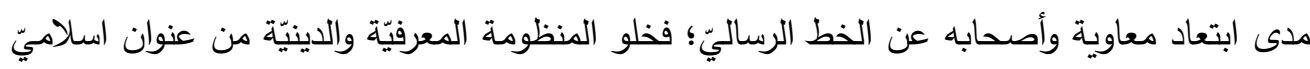

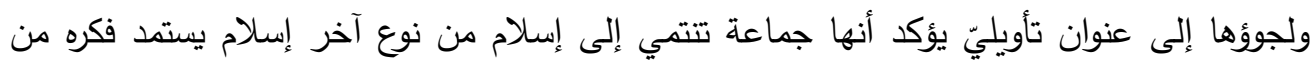
الإطار الذي رسمه له معاوية، أي: إنه إسلام سلطة. وربما يتبين السبب التخاطبيّ في هذا الإخبار من النبي (صلى الله عليه اللهايه واله وسلم) بإيضاح مقاصد الأفعال أمام المتلقي والاعتماد على الدلالات الحقيقية للألفاظ، كيما تعجز ذهنية المتلقي ألياً

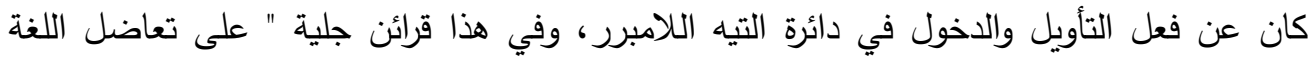


العدد الثالث والأربعون

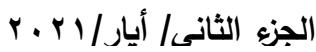

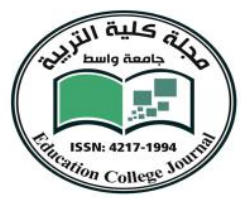

والسياسة ما ييوئها منزلة الصدارة في استكشاف الخفايا المخاتلة التي تصوغ مكر الخطاب. تلك الظاهرة ذات وجهين: الأول أن فعل التسمية أصبح يتجول بين زمنين: ما قبل الحدث وما بعده، فليس مفروغاً منه ألا يولد الاسم إلا بعد ولادة من تراد تسميته، بل قد يتم اتخاذ القرار بشأن إحداث الصراع

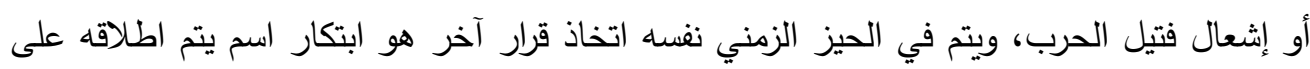

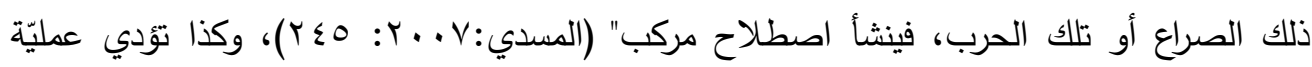
اطلاق الاسم على الحرب تأثيراً نفيًّا على المشاركين فيها، فلما قال الإمام علي عليه السلام: " أُمِرتُ بقتال ثلاثة، الناكثين والقاسطين والمارقين، أمّا القاسطون فأهل الثام، وأمّا الناكثون فأهل

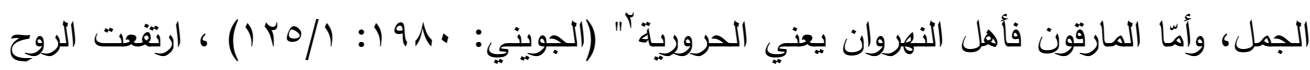
المعنويّة لدى جيشه؛ لأنهم على الحق بشهادة الرسول (صلى الله عليه واله وسلم)، في حين يرتد هذا

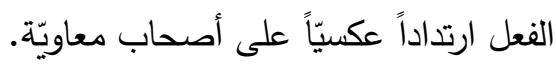

وما دمنا في دائرة الكلام عن العنوان، فنلحظ أن المشهد الحربيّ قد وسم الجيشين بأسماء تبعاً للجهة التي خرجوا منها، فجيش الإمام الذي خرج من العراق سميّ جيش أهل العراق والجيش القادم من الثام سميّ جيش أهل الثام، وهذا يوضتح أثر المكان في أطلاق التسمية في هذه المعارك هن فالمعركة هي صفين نسبة للأرض التي حدثت فيها، وهو أسلوب قديم استخدم في معارك الإسلام الاولى مع الرسول (صلى الله عليه واله وسلم) فنجد معركة أحد نسبة للجبل، ومعركة تبوك نسبة للمدينة التي وقعت الحرب فيها.

\section{ع - البنية المعجميّة للرسائل:}

مراجعة المعجم العربيّ لمعرفة الأصل اللغويّ لكلمة (رسالة) نجد فيه أن "الرَّاءُ وَاليِّينُ وَاللَّاَمُ

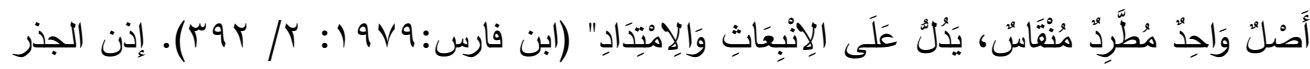

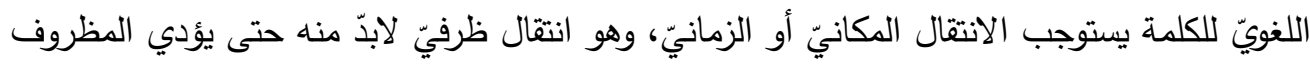

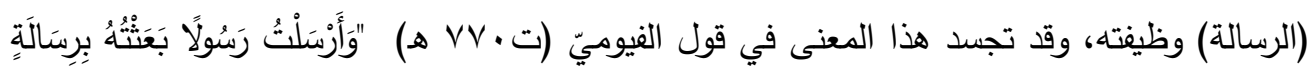

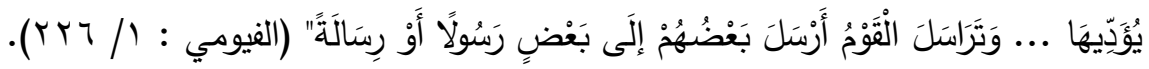

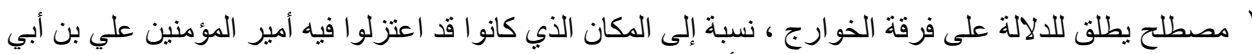

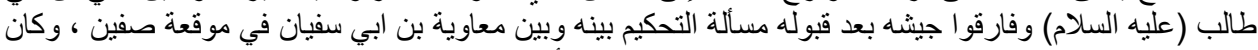

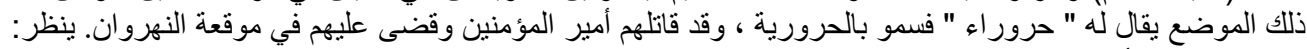

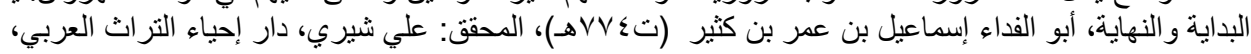


العدد الثالث والأربعون

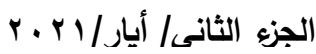

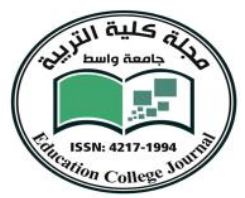

وتباين تتاول المعجم العربيّ المعاصر عن تتاول المعجم القديم، فقد اتسعت موارد استعمال الكلمة

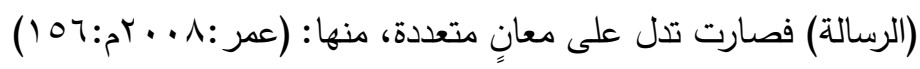

1- خطاب حرَّر رسالة- بعَث برسالة مسجَّلة- رسالة مُشفَّرة.

r- كتابٌ موجز يشتمل على قليل من المسائل تكون ذات موضوع واحد، نحو: (رسالة ابن سينا في

أسباب حدوث الحروف، ورسالة الغفران لأبي العلاء المعرّيّ).

ب-وسيلة اتصال تتقل بالكلمات أو الإشارات أو بوسيلة أخرى من شخصٍ ما أو محطّة أو من مجموعة لأخرى.

ع- الرّرسالة الإخباريّة: تقرير مطبوع يزوّد بالأخبار والمعلومات ذات الأهمية لجماعة معينة. ه-بحث مُبتكر يقدم للحصول على شهادة عليا وتسمى في بعض البلاد العربية أُطروحة "رسالة ماجستير / دكتوراه.

وعمليّة الارسال هذه تستدعي بالضرورة مرسلاً ومرسلاً إليه، وهما المتخاطبان في الأساس وما الرسالة إلا واسطة للتواصل والتخاطب، وهي على هذا حدث تخاطبيّ من مطلعها في صيغته الثابتة (من .... إلى )، وتظل حاوية مقاصد المرسل ومراده، وتتباين هذه المرادات بحسب الغرض الذي من أجله سيقت الرسالة، فهي مرة تكون حاملة مضامين إخبارية، وأخرى تحمل قصداً إقناعياً تأثيرياً،

وممّا يُلحظ أن مدونة المنقريّ لم تعنون هذه الرسائل بعنوان (رسالة)، بل استعمل المنقري مصطلح (كتاب)، فيقول مثلاً: كتاب علي أمير المؤمنين إلى عماله.

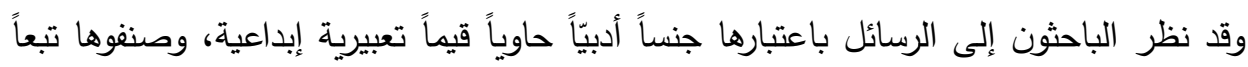

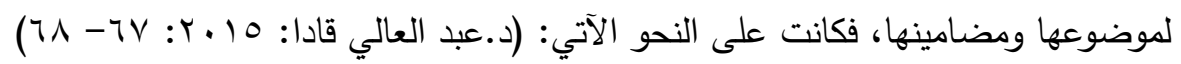
1-الرسائل السياسيّة ( الديوانيّة، السلطانيّة)، وهي الرسائل ذات المضامين الرسميّة الصادرة من

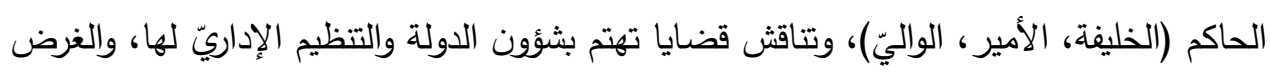
منها فرض سلطة الحاكم على أبناء دولته.

r-الرسائل الاجتماعيّة (الاخوانيّة، المكاتبات، المراجعات)، وهي رسائل ذات مضامين مجتمعيّة وتتعرض لشؤون الاصدقاء والإخوان ومراسلاتهم ذات الموضوعات الخاصة بهم، والغرض منها التواصل بين الإخوان والأصدقاء.

r-الرسائل الدينيّة، هي الرسائل ذات المضامين الدينيّة، وتتاقش قضايا دينيّة كالالتزام بالصلاة والصوم، والتحليّ بالأخلاق والأمر بالمعروف والنهي عن المنكر، والغرض منها وعظيّ تربويّ، 
العداند الثالث والأربعون

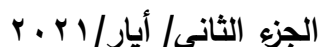

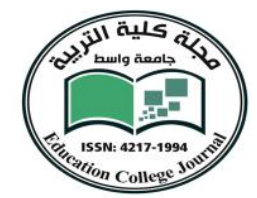

وكل ما من شأنه أن ينشر التعاليم الدينيّة ويؤدي إلى تطبيقها، ودائماً ما تصدر هذه الرسائل من الفقهاء.

ع - الرسائل الأدبيّة، هي الرسائل ذات المضامين الأدبيّة، وتناقش موضوعاً أدبياً انشائيّاً والغرض منها أدبيّ، وفي الغالب يكون امتاعيًاً.

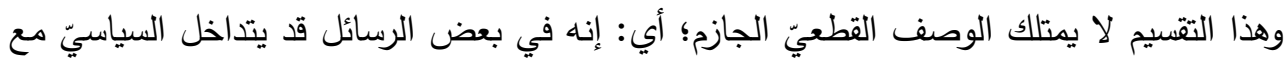

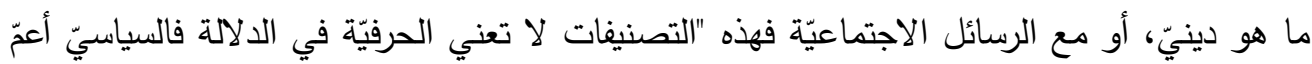

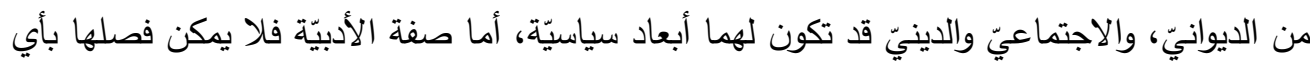

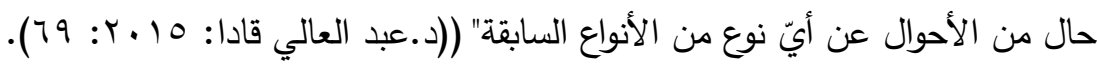

\section{ه- السمات التداوليّة للرسائل:}

لقد اعتمدت تقسيمات الرسائل على معايير نابعة من البنيّة الموضوعيّة لها؛ فنظر (التقسيم) إلى لى

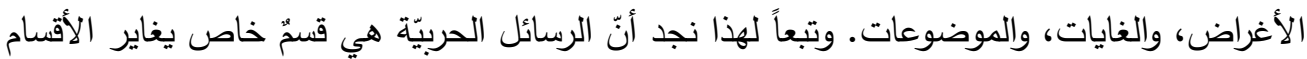

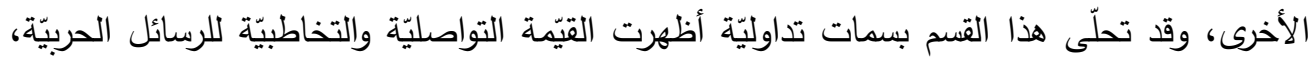

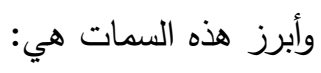

1-الغرض: إن الغرض الذي من أجله كتبت هذه الرسالة هو إقناع المرسل إليه بتغيير سلوكه من

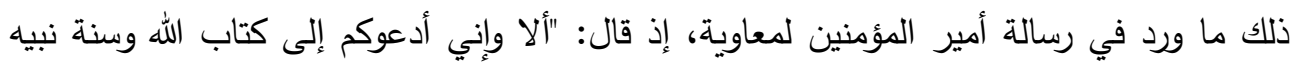

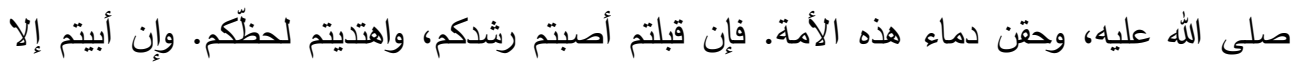

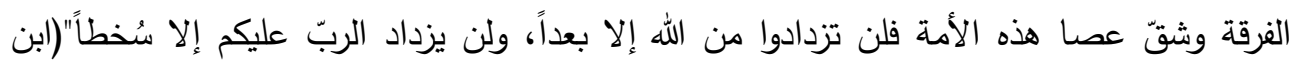

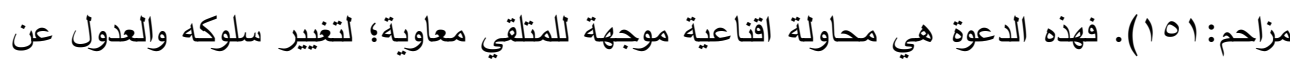
أفعاله السابقة والدخول مع أمر الجماعة التي اختارت أمير المؤمنين، وهذه المحاولة لا تستلزم

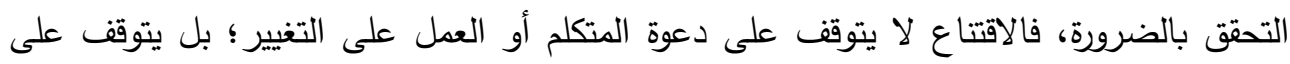
رغبة المتلقي بالتغيير ومدى استعداده لنجاح الفعل الاقناعيّ.

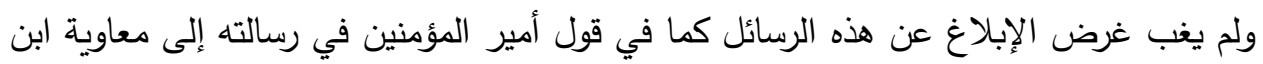

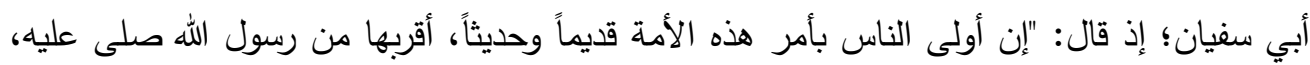

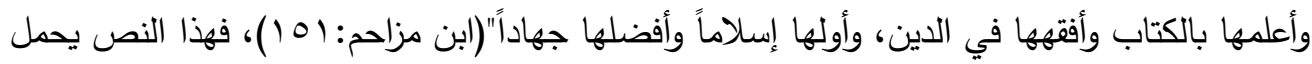

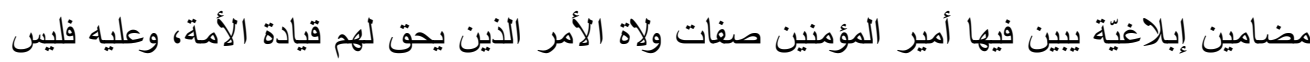
من حق معاوية وأمثاله التصدي لهذا الأمر . لمنائ. 
العدد الثالث والأربعون

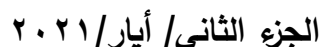

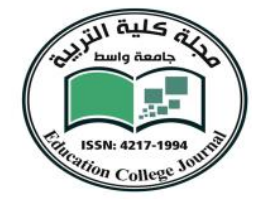

وقد تضمّنت بعض هذه الرسائل غرضاً دعوياً، إذ كان الإمام علي (عليه السلام) يبعث رسائله إلى العمال على الأمصار الإسلاميّة، طالباً منهم مبايعته، وهذه الرسائل لم تكن حربيّة مباشرة؛ بل هي مقدمة للحرب، يجمع فيها أمير المؤمنين عامليه ويكتشف من منهم معه، ومن هو مخالف لأمره، ولا سيما أنها أرسلت بعد وقعة الجمل في البصرة، ومن هذه الرسائل ما بعثه إلى الأشعث بن قيس الكندي عامل أذربيجان، وقد ورد فيها: "أما بعد فلولا هنات كن فيك كنت المقدم في هذا الأمر قبل الناس ولعل أمرك يحمل بعضه بعضاً إن اتقيت الله ... وأنت من خزان الله عليه حتى تسلمه إلي

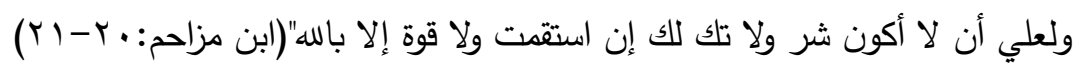
r-المضمون: تحتوي الرسائل الحربيّة على مضامين اقناعيّة ارشادية كالتي عرفناها في النقطة (1)، وهناك كذلك مضامين استفزازيّة كالهجوم على المرسل إليه، أو الوعيد، والتعديد كما في جواب معاوية عن رسالة أمير المؤمنين آنفة الذكر، إذ اقتبس بيت من قصيدة عمرو بن الأهتم: (ابن

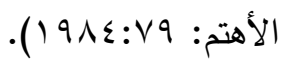

$$
\text { لَيسنَ بَيني وَبَينِ قَيسٍ عِتابُ }
$$

فهو في اقتباسه هذا كسر فعل الإقناع ورفض الاقتتاع، راداً بهجوم قوليّ يعكس تبييته لنية

$$
\text { الحرب وإشعاله دونما عناية في مدياتها وما سينتج عنها. }
$$

r-الموضوع: يظل موضوع الحرب القائمة بين الطرفيّن هو المسيطر على الجو العام للرسالة، فكل محتوياتها تتاقش ما يرتبط بأرض المعركة، نحو: حق المرسل بالسيطرة على زمام الأمور، ووجوب لهوبن انصياع المرسل إليه كما في ما تقدّم، وقد نلمح موضوعاً آخر كما في رسالة معاوية للإمام علي بلي التي يطلب منه فيها التوقف عن القتال وجعل الأمور على ما هي عليه، فقال: "وإنّا وإن كنا قد غُلِبنا على عقولنا فقد بقى لنا منها ما نندم به على ما مضسى، ونصلح باه ما بقي. وقد كنت سألتكاك

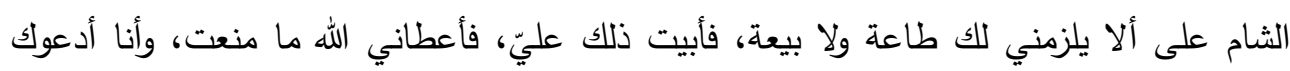

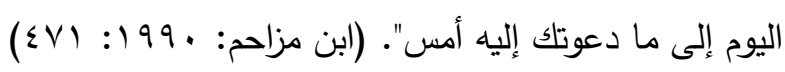

ع-قد يبتعد أحياناً مضمون الرسالة عن الحرب والمعركة، ويناقش قضايا دينيّة أخلاقيّة كرسالة الإمام في بداية الأحداث قبل أن تقوم الوقعة أو يحتدم الجيثان، إذ بعث برسالة إلى معاوية قال فيها: "إنه

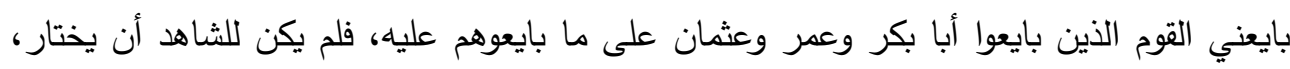
ولا للغائب أن يرد، وإنما الثورى للمهاجرين والأنصار، فان اجتمعوا على رجل وسموه إماما كان ذلك لله رضا، فإن خرج عن أمرهم خارج بطعن أو بدعة ردوه إلى ما خرج منه، فان أبى قاتلوه على الى اتباعه غير سبيل المؤمنين، وولاه الله ما تولى. ولعمري يا معاوية، لئن نظرت بعقلك دون هواك، 
العدد الثالث والأربعون

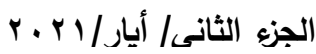

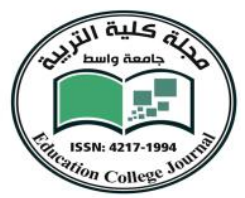

لتجدني أبرأ الناس من دم عثمان، ولتعلمن أنى كنت في عزلة عنه، إلا أن تتجنى، فتجن ما بدا لك!

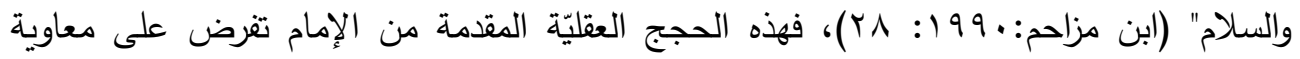
وجيشه النزول عند إرادة أمير المؤمنين؛ لأن الخروج عليه سيلحقه فساد وإفساد لشؤون الأمة. ومع الئ هذا يظل الوصف الحربيّ ملاصقاً لها؛ لأنها تُعد مقدمة للحرب وعاملاً مؤثراً في حركتها.

\section{צ- إفادة المتكلم من سياقات المقام في إيصال مقاصده:}

يختار المتكلّم البنية اللفظيّة الصادرة منه تبعاً للمعجم الذهني الذي يختزنه؛ وتظهر هذه البنية معبرة عن انطباعاته وقناعاته اتجاه قضايا المجتمع الذي يعيشه، ولا يتحدد السياق الذي نحن بصدد عرضه بالزمان أو المكان الذي قيل فيه الكلام؛ بل هو "جملة الموقف المتحرك الاجتماعيّ الذي يُعتبر المتكلّم جزعاً منه، كما يُعتبر السامع والكلام نفسه، وغير ذلك ممّا له اتصال بالتكلّم، وذلك أمر هر يتخطى مجرد التفكير في موقف نموذجي، ليشمل كل جوانب عمليّة الاتصال من الإنسان والمجتمع

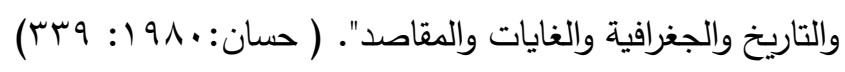

وللسياق أثر كبير في انجاح فعل التواصل بين المرسل والمرسَل اليه، ولا يمكن اختزال الرسالة من ظروف نشأتها المحيطة بها؛ وأهمية السياق في صياغة القول جعلت جاكبسون يعده من العوامل المكونة لكل سيرورة لسانية ولكل فعل تواصلي لفظي، فهو يرى أن "المرسل يوجه رسالة إلى المرسل إليه، ولكي تكون الرسالة فاعلة، فإنها تقتضي -بادئ ذي بدء- سياقاً تحيل عليه (وهو ما يدعى أيضا "مرجع" باصطلاح غامض نسبياً) سياقاً قابلاً لأن يدركه المرسل إليه، وهو إما أن يكون لفظياً أو قابلاً لأن يكون كذلك؛ وتقتضي الرسالة، بعد ذلك سنناً مشتركاً، كلياً أو جزئياً، بين المرسل لئل والمرسل إليه (أو بعبارة أخرى بين المسنن ومفكك سنن الرسالة) وتقتضي الرسالة، أخيراً، اتصالاً، أي قناة فيزيقية وربطاً نفسياً بين المرسل والمرسل إليه. اتصالاً يسمح لهما بإقامة التواصل والحفاظ عليه"

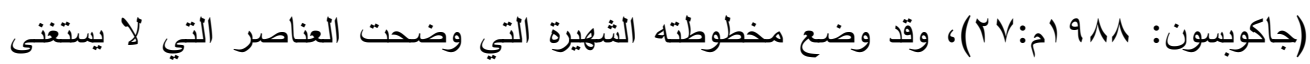
عنها في التواصل اللفظي، وهي على النحو الآتي: سياق

مرسل -----

سنن 
العدد الثالث والأربعون

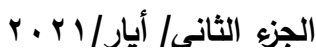

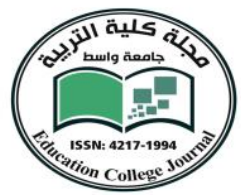

وبهذا الفهم الواسع للموقف نجد أن أصحاب المراسلات الحربية أيدوا آراءهم ومواقفه بجملة إحالات على مواقف زمنية، واجتماعية، وتاريخية أفادوا منها في بيان مقاصدهم وفي إيصال غايات كتاباتهم إلى الآخر، من هذا ما ورد في رسالة الإمام علي (عليه السلام) إلى معاوية؛ إذ قال: " لعمري لئن نظرت بعقلك دون هوالك لتجدني أبرأ قريش من دم عثمان. واعلم أنك من الطلقاء الذين لا تحل لهم الخلافة، ولا تعرض فيهم الشورى" (ابن مزاحم: 9 ب: . 99 ()). فهذا المقطع من رسالة الإمام قد تضمن ذكراً لسياقات تأريخية، فقد ذكر الإمام حادثتين؛ الأولى: هي مقتل عثمان بن عفان، وهي الحادثة التي سيتكرر ذكرها كثيراً باختلاف زاوية النظر إليها، وزاوية النظر التي اتخذها أمير المؤمنين هي براءته من دم عثمان، وقصده من هذا العرض هو تدعيم موقفه الثخصي، وموقف جبهته، فالأمير لابد أن يكون سليم الجانب من أي شائبة، ولا يمكن أن يكون عرضة للاتهام وموقعاً لسهام الثبهة. والحادثة الأخرى التي عرضها هي (الطلقاء)، والقصد منه بيان حقيقة المقابل (معاوية)، والكثف عن ابطال حكومته الآن ومستقبلاً، وهو فيه إحالة على الحدث التاريخي المعروف؛ إذ حينما فتح رسول الله (صلى الله عليه وآله وسلم) مكة عنوة " خطب على باب الكعبة ثم قال بعد كلام: " يا معشر قريش! ما ترون أنى فاعل فيكم ؟ قالوا: خيراً. أخ كريم، وابن أخ كريم، قال: اذهبوا فأنتم الطلقاء... وكان فيهم معاوية ابن أبي سفيان" (ابن الأثير:

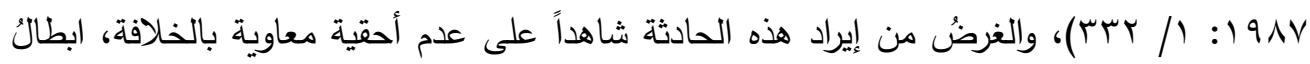
دعاوى معاوية، وكثف زيغها أمام الجيشين. وفي اختيار هذين الحادثين اللذين شهدها كثير من الناس من أهل مكة أو المدينة أو حتى الثام الذين كانوا حاضرين في ذلك الوقت، فيه عناية بالعقل الجمعيّ للمشاركين في الحرب، وهو بهذا اعتى بالمتلقي بعدم اكتفائه أثناء كلامه بالسرد، لأن "المرويات تحمل في طيها معلومات تظل تتقصها مكملاتها مما يحمله السياق المقامي من قرائن تقيد

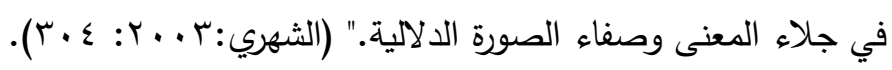

وقد مثّل قتل عثمان علامة فارقة في رسائل معاوية، حتى ذهب مثلاً فيقال للأكر الذي يُدعى له باطلاً: (قميص عثمان)، ولكن زاوية النظر اختلفت عن تلك التي عرفناها عند أمير المؤمنين، فحينما كان يبعد التهمة عنه، حاول معاوية اثباتها مستعملاً وسائله كافة، التي منها تكرار الدعوة في

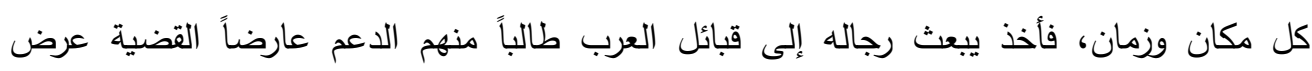
المسلمات، وقال في أحدى رسائله إلى أصحابه مبيناً سبب خروجه على أمير المؤمنين: "إنما نطلب بدمه [ يقصد عثمان] حتى يدفعوا إلينا قتلته فنقتلهم بكتاب الله. فإن دفعهم علي إلينا كففنا عنه، وجعلناها شورى بين المسلمين على ما جعلها عليه عمر بن الخطاب" (ابن مزاحم: •99 1 : با7). 


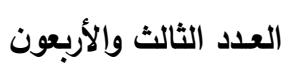

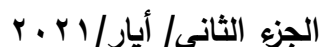

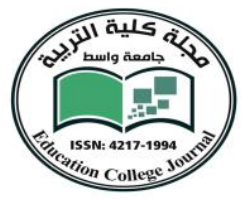

وجعلها معاوية محور خروجه والعصا التي اتكأ عليها. وهو أمر تباين فهمه عند جمهور المتحاربين، الأمر الذي جعل من الفعل اللغويّ (نطلب)، فعلاً فاشلاً لم يحقق قدرته الإنجازية الكاملة؛ لأن أبرز شرط وضعه أوستن لتحقيق إنجازية الفعل هو "يجب في كل حالة مفترضة أن يكون الأشخاص المعنيون والملابسات المخصوصة جميعاً على وفق المناسبة والملاعمة حتى نستطيع أن نتمسك بذلك النهج المحتكم إليه في إنجاز الأفعال اللغوية بنجاح" (أوستن: 199 1: 9 ؛) . ومما يلحظ على النص السابق أنه يذكر كلمة الثورى، والتي يعاد ذكرها عند أمير المؤمنين، ولكنّ غرض الذكر يتباين هنا؛ فقال: " أحق الناس بنصرة عثان أهل الثورى من قري الذين أثبتوا حقه واختاروه على غيره وقد نصره طلحة والزبير وهما شريكاك في الأمر ونظيراك في الاسلام وخفت (معهما) لذلك أم المؤمنين فلا تكره ما رضوا ولا ترد ما قبلوا فإنما نريد أن نردها شورى بين المسلمين". (ابن مزاحم: • 99 (: V0)؛ لأنه أراد التعريض بمعاوية والتجريح به واستصغار شأنه. ويبدو أن ذكر معاوية لحادثة تاريخية لم يكن طرفاً فيها ولم يحضرها هو محاولة منه لإقناع

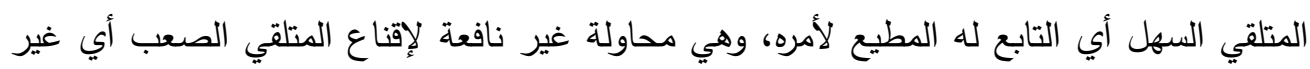
المطيع له والمخالف لأمره، ومرة أخرى ينتقل معاوية الى خرق جدار النجاح ويعدل بالفعل اللغويّ الى لى

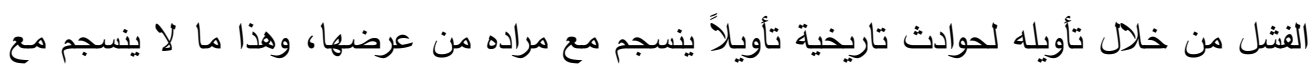
الخطاب الإقناعي؛ لأننا إذا رمنا الإقناع فعلينا البحث عن كل الأوضاع والظروف التي قيلت فيها

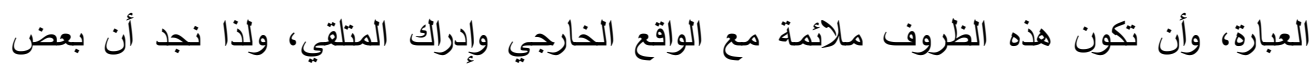
صحابة رسول الله أحسَّوا بمقصد كلامه وغايته؛ فردوا دعواه عليه، فقد أبطل سعد بن أبي وقاص

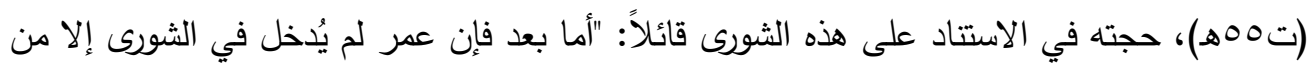
تحل له الخلافة، فلم يكن أحد أولى بها من صاحبه إلا باجتماعنا عليه غير أن علياً كان فيه ما فينا

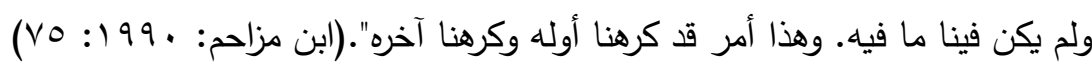
وبالإضافة إلى هذه السياقات حاول طرفا الصراع الاستتاد على حال المسلمين؛ لتدعيم دعواهم

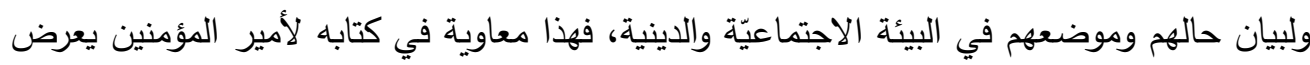
أحوال المسلمين بعد وفاة النبي قائلاً: " إنّ الله اصطفى محمّداً بعلهه وجعله الأمين على وحيه والرسول إلى خلقه، واجتبى له من المسلمين أعوانا أيّده الله بهم، فكانوا في منازلهم عنده على قدر فضائلهم في الإسلام ، فكان أفضلهم في إسلامه وأنصحهم الله ولرسوله الخليفة من بعده، وخليفة

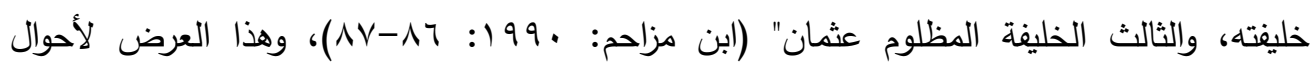
المسلمين خاضع لغايات المتكلم وبحسب رغبته في كسب الجمهور المتلقي، ممّا استدعى أمير 
العدد الثالث والأربعون

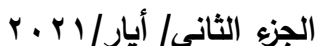

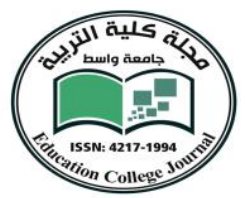

المؤمنين لرد هذا القول عليه ورفضه والكشف عن أحوال المسلمين بعد وفاته كما وقعت وليست كما ادعى معاوية، إذ قال: " إن مححاً صلى الله عليه وآله لهّا دعا إلى الايمان بالله والتوحيد كنّا أهل البيت أوّل من آمن به، وصدّق بما جاء به... فأمّا من أسلم من قريش بعد، فإنّهم مدّا نحن فيه أخلياء، فمنهم حليف ممنوع أو ذو عشيرة تدافع عنه، فلا يبغيه أحد بمثل ما بغانا به قومنا من التلف" (ابن

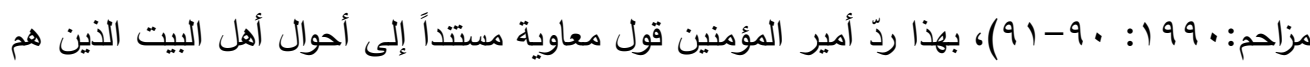
أولى بالنبي من غيرهم، فهم من تحمل الأذى وصبر على البلاء، وعُزلوا من مخالطة الناس، وما هذا إلا لأنهم أهله وخلفاؤه. ولم يكن التتاقض الحاضر بين الصورتين إلا بسبب التتاقض في انتماءات المتكلمين، فكل منهم يخضع عباراته لانتماءاته الدينية، والاجتماعية.

- V تعد الغايات والمقاصد التخاطبية (إبلاغية وإفهامية) أساساً مهماً في تصدير المتكلّم كلامه؛ وهذه الغايات تتأطر بدوافع نفسيّة يحاول فيها المتكلم إظهار عقيدته ومتبنياته الفكريّة وما يؤمن به فالنص "يتأسس على مقاصد توظف فيها اشارات استجابة لنسق يتطلب بناء الانسجام من جهات العلاقات الخفية التي تسهم في تتظيمه، ويؤلف عالمه المتخيل تأليفاً يكفل وحي الدلالات" (الشيدي:

$$
\left.\cdot(1) 1::_{0}+1\right)
$$

وهذه المقاصد تباينت بحسب تباين معتقدات المتكلمين فاتخذت صوراً يمكن اجمالها بحالات "الاعتقاد والخوف والأمل والحب والكراهية والبغض والميل والنفور والثك والتعجب والابتهاج والعجب والحزن والقلق والغرور والندم والأسى والأسف والثعور بالإثم والغرح والغضب والارتبالك والقبول والصفح والخصومة والنزوع والتوقع والاعجاب والازدراء والاحترام والسخط والقصد والتمني والرغبة

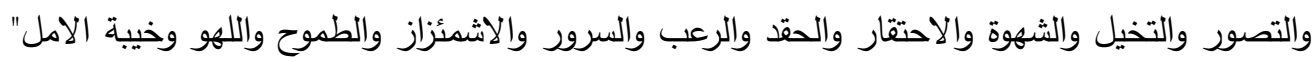

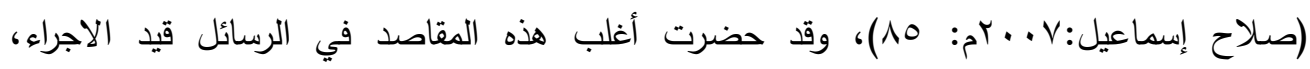
فالمتراسلانِ كثيراً ما كانا يصيغان تراكيبهم اللفظيّة؛ تبعاً لعقيدتهم ولما ينتجه الموقف التخاطبي من دوافع نفسية تفرض على المتكلّم صياغة خاصة للتراكيب واختياراً معيناً لألفاظه، من هذا ما ورد في تئي رسالة أمير المؤمنين إلى معاوية: "بسم الله الرحمن الرحيم من عبد الله علي أمير المؤمنين إلى معاوية بن أبي سفيان، سلام على من اتبع الهدى، فإني أحمد الله إليك الذي لا إله إلا هو" (ابن مزاحم: • 99 (: 1 • (1). إنّ وسم أمير المؤمنين بأنه عبد الله دلالة على ما ارتكز في نفسه من قيم دينية 
العدد الثالث والأربعون

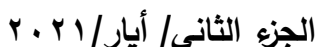

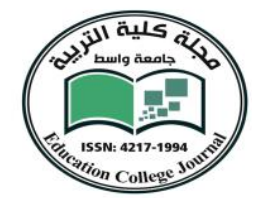

اعتقادية؛ فالأساس عنده عبادة الله والالتزام بأحكامه وهو إثارة إلى أنّ العلاقة بين الناس في نظره تُبنى على أساس العلاقة باله، فقد ربط الفعل اللغويّ (أحمد الله) الذي أنجزه بالواقع النفسيّ والعقديّ له، وهذا ما ألمح إليه الباحثون اللسانيون في ما بعد؛ فقد قرر فندريس أن كل فعل لغويّ يحمل أثراً انفعالياً، فهو عنده عبارة عن تعبير خاص ينتج انفعالاً معيناً، فلا يعطي شخص ما المعلومات ذاتها

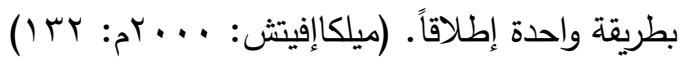
وممّا يلحظ على صيغة السلام التي خاطب بها الإمام علي (عليه السلام) معاوية بن أبي سفيان، أنه كان دائماً ما يقول (سلام) أو (السلام)، وقد تغيرت هذه الصيغة مرة واحدة في الرسائل بينهما، فقال (سلام عليكم)، والسبب في هذه المرة أنه وجه كلامه إلى (معاوية وإلى من قبله من قريش)، أضف إلى هذا ما قرره أمير المؤمنين من خروج معاوية عن الهداية ودخوله في دائرة

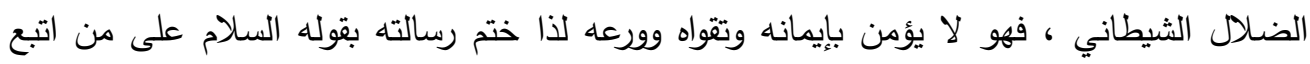

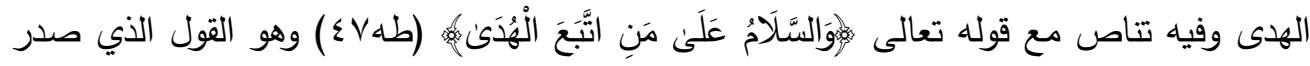
من موسى الى فرعون بأمر الله، فاختار الإمام كلماته بحسب الجو العام الذي صيغت من أجله؛ لأن "الكلمات كالماء الذي يخضع لونه للون انائه، وإنما هي كالحرباء التي تتلوّن بلون المكان الذي تحل فيه؛ أي إن الكلمة أشبه بالحرباء تمتلك امكانات معينة، كل منها يبرز في موضعه المناسب، وليست كالماء الذي لا يملك شيئاً من تلك الأكانات وإنما يخضع لما يفرض عليه من الخارج".(يونس:

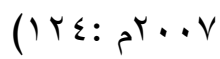

وكذلك يتبين هذا الأثر في قول الإمام علي (عليه السلام) لمعاوية بن أبي سفيان: " ومتى كنتم

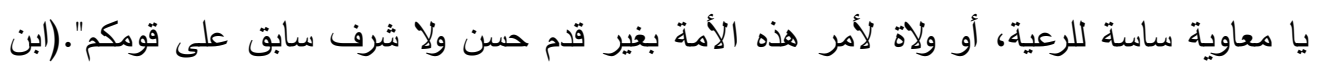
مزاحم: .99 19: 9 ـ (1) فتركيب الاستفهام المجازي عكس اعتقاد المتكلّم بأن معاوية ليس أهلاً لسياسة

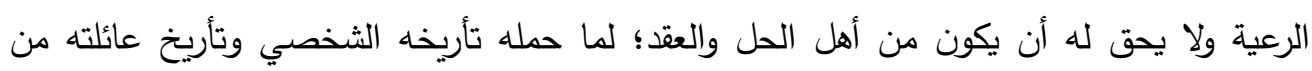
خروج عن أوامر الدين ونواهيه.

وتظل عقيدة أمير المؤمنين هي الواعز لتكوين عباراته وألفاظه، ويتضح هذا في مقارنته بين اختيار الناس والاختيار الإلهي، وأنه لا يحق للناس الوقوف بوجه الاختيار أو الاعتراض عليه فقال: "واعلم أن هذا الأمر لو كان إلى الناس أو بأيديهم لحسدونا وامتنوا به علينا ولكنه قضاء ممن امتن به علينا على لسان نبيه الصادق المصدق" (ابن مزاحم: •99 19: • (1))، ولا تتنهي هذه الرسالة إلا وهو يؤكد على انتمائه للرسول (صلى الله عليه وآله وسلم) وإيمانه به فهو عنده الصادق المصدق، وفي 
العدد الثالث والأربعون

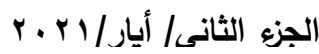

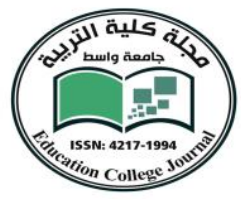

هذا الوسم للنبي احالة ضمنية الى الوعد الذي وعده النبي لأمير المؤمنين أن سيقاتل معاوية وجماعته وقد مر ذكره.

وقال معاوية ابن أبي سفيان جواباً عن كتاب أمير المؤمنين: " أما بعد فدع الحسد فإنك طالما لم تتتفع به، ولا تفسد سابقة قدمك بشره نخوتك".(ابن مزاحم: •99 ا: . 11) يحاول معاوية في رسالته هذه أن يلتبس لباساً غير لباسه، ويتقصص شخصيةً أخرى، إذ تحول إلى إنسان ناصح واعظ يحاول جهده لثي أمير المؤمنين عن مواقفه، ونستطيع تكثف دواخل النفس من ظواهر الكلام، ومحاولة التظاهر بمظهر شخصية أخرى أو لبس لبوسها والتصرف على هيأتها فتحوله إلى إنسان صالح آمر بالمعروف ناه عن المنكر، ولكن هذا التلون تكثفه طيات اللسان؛ لأن "القول دليل على الى إلى إلى ما في الذهن وما في الذهن صورة لما في الوجود مطابقة له، ولو لم يكن وجود في الأعيان لم تتطبق صورة في الأذهان ولم يشعر به الإنسان ولم يعبر به باللسان".(الغزالي:1 97 1: • 1-11) فوسمه

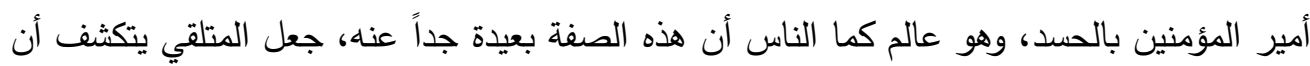
الحقد والبغض هو الذي يختار الألفاظ وهو ما صنفه جيرار جينيت ضمن فرضيتين؛ الأولى: فرضية الكثف اللاإرادي عن طريق فلتات اللسان الكاشفة لشخصية لا واعية للمتكلم ، والفرضية الثانية: هي هي

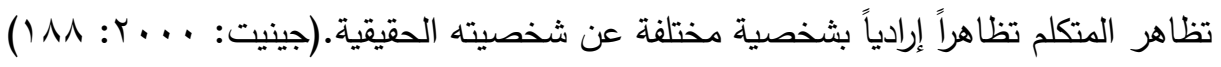
وإذا رمنا أن نترك المراسلة بين القيادة وننتقل الى المراسلة بين الجنود فنجد أن رسالة محمد بن أبي بكر (تى^هـ)، أكثر رسالة يظهر فيها تأثير العقيدة في صياغة التركيب فمداليل الكلمات تبرّز عقيدة المتكلمّ وتتبئ عن متبنياته؛ فهو قد صاغ عباراته تبعاً لمعتقده وما رسخ في ذهنه ونفسه، ومما قال في رسالته: "من محح بن أبي بكر إلى الغاوي بن صخر • سلام على أهل طاعة الله ممن هو مسلم لأهل ولاية الله" (ابن مزاحم: •99 19: 11 1). تبرز اللغة الانفعالية واضحة جلية في وصف المتكلّم المخاطبَ بأنه غاوٍ أولاً، وهي الصفة التي اعتقدها في مخاطبه؛ فمحمد مؤمن بأن معاوية إنسان بعيد

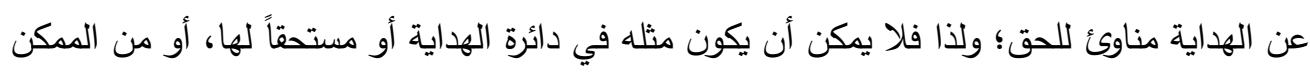
أن تحيط به عناية الله.

وقد شحن المتكلّم ألفاظه بطاقة انفعالية عالية؛ وذلك حينما استعمل اسم والد معاوية الصريح (صخر)، ولم يُكني، علماً أن كناية أبي سفيان هي التي تعارف عليها في النداء لا الاسم الصريح وهو الأمر الذي عليه عامة العرب، حتى من تخاصم مع معاوية كأمير المؤمنين، ولكن لـّا امتلأت نفس محمد غيظاً وبغضاً على معاوية رفض الكناية وعدل إلى التصريح وهو تعريض ضمني باستحقار هذا النسب، وهو ما كان يكرره دائماً وفي أي مناسبة أو مقام يُذكر فيه معاوية وأهله، وبالمقابل كان 
العدد الثالث والأربعون

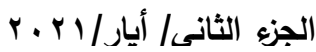

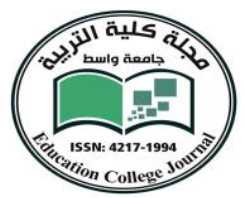

دائماً ما يمدح أمير المؤمنين ويفتخر أنه من مريديه والمقربين له من هذا قوله: "فلم يبرح مبتذلاً لنفسه في ساعات الأزل ومقامات الروع. حتى برز سابقاً لا نظير لله في جهاده، ولا مقارب له في فعله، وقد رأيتك تساميه وأنت أنت. وهو هو المبرز السابق في كل خير ـ أول الناس اسلاماً، وأصدق الناس نية، وأطيب الناس ذرية، وأفضل الناس زوجة، وخير الناس ابن عم، وأنت اللعين ابن اللعين ... فكيف -

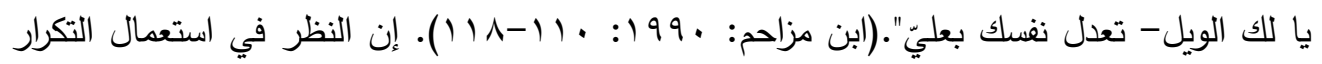
للضمير المنفصل أنت أنت وهو هو على ما فيه من قوة احالية، يخلق جواً من التقابل المعنوي بين الاثثين، وقد جمع في تكرار هذا الضمير صورتين متقابلتين مبالغ فيهما الأولى صورة معاوية المستحقرة الدنيئة، وكأني أراه -حمح بن أبي بكر - قد قطب حاجبيه واشمأز حال نطقه بالضمير المؤكد، والأخرى صورة أمير المؤمنين الرفيعة الثأن التي يؤطرها الصدق والوفاء والإخلاص والالتزام بالقيم الدينية وهما صورتان غير قابلتين للتساوي أو التعادل.

\section{ᄉ- مقاصد الإخبار والاستخبار : مقإ}

الإخبار هو نقل الخطاب أو محتوى الخطاب بما يتضمنه ذلك النقل من سبل إبانة عنه، ولما كان الإخبار نقلاً للخطاب أو محتواه كان بذلك إخباراً عنه واعلاماً به، والإبلاغ حين يرتبط بالكلام

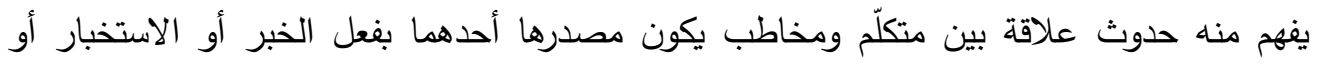

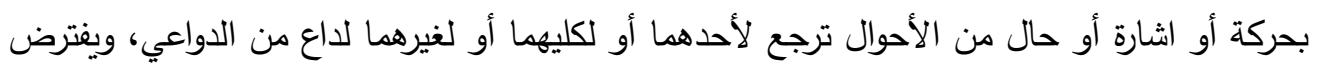

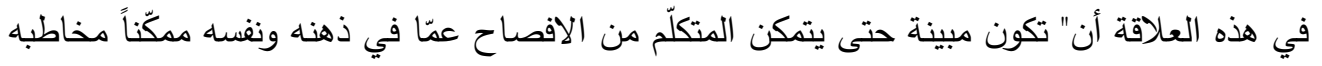

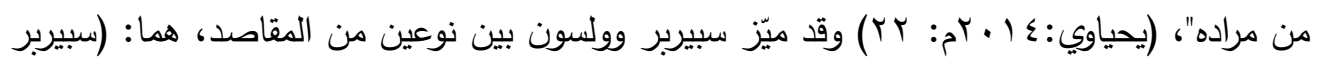

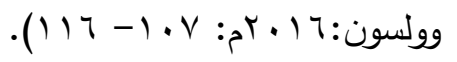

الأول: القصد الإخباري: الذي يكمن في رغبة المتكلّم في إبلاغ المخاطب المحتوى القضويّ، وينظر التداوليون الى هذا النوع من المقاصد بوصفه قصداً لتوليد توجهات معينة لدى المخاطب تجاه

قضايا معينة.

الثاني: القصد التواصلي: وهو أن يكون القصد الاخباري معروفاً ومعلوماً لدى المخاطب، فمجرد اخبار المخاطب بقصدك الإخباري لا يكفي تماماً لإنجاز عملية التواصل. ويبني المتكلّم عملية الإخبار على أساس المقاصد الكلامية القارة في ذهنه ونفسه، ومراجعة الرسائل الحربية تبين هذه المقاصد من خلال السياقات الواردة فيها، ومن صور الإخبار ما يقصد به التواصل بين المتراسلين ومنه قول أمير المؤمنين في رسالة الى جرير : "إني أخبرك عن نبأ من سرنا 
العدد الثالث والأربعون

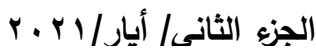

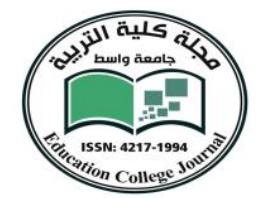

إليه من جموح طلحة والزبير عند نكثه بيعتهم وما صنعوا بعاملي عثمان بن حنيف ... فاسأل عمّا بدا لك"، (ابن مزاحم:•99 1: 10) فكان قصد الإخبار هنا هو التواصل مع المخاطب، والاستخبار عن مستوى تفاعله مع الخبر الواصل له، فلم يكن ذكر الحدث التاريخي والفعل الذي قام به أمير المؤمنين تجاه طلحة والزبير مجرد سرد لخبر يراد به الإعلام، بل كان الذكر لإيصال معلومة

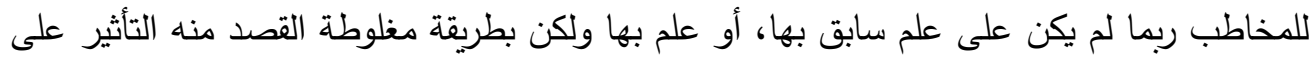
جرير، ولما أخبر أمير المؤمنين، أكد على فعل التواصل بقوله "اسأل ما بدا لك" ليزيل بهذا القول كل عملية استفهام كانت تدور في ذهن المخاطب أو الجماعة القرببة منه وليكون العمل اللغوي مقنعاً للمخاطب، ويحصل به الاقناع وليس الإذعان للأوامر فحسب وهو من المقاصد العامة التي بني عليها الخطاب العلوي الثريف، فأمير المؤمنين لا يعتني بفعل الإذعان والإقرار من الآخر إن لم يكن على قناعة تامة، وهذا الفعل السلوكيّ يختزنه أمير المؤمنين في ذهنه ولا يفرق بين المخاطبين في ضرورة حصول فعل الاقناع قبل الإقدام، بعيداً عن الترغيب أو ترهيب. وبالبحث في متون الرسائل نجد حضور قصد آخر من مقاصد الإخبار، وهو الإخبار من أجل التأثير في المخاطب وتغيير قناعاته أو سلوكه، من هذا ما ورد في رسالة معاوية لشرحبيل، والتي جاء فيها: " إن هذا الأمر الذي قد عرفته لا يتم إلا برضا العامة، فسر في مدائن الثام، ونادِ فيهم

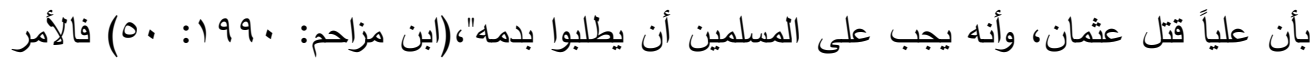

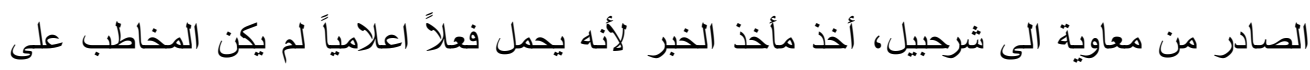
علم به، وقد أضاف معلومة جديدة له والقصد منه التحرك لتحشيد الجماهير واخبارهم بأن أمير المؤمنين هو من قتل عثمان، وعليه يجب على الأمة أن تتحرك في سبيل الاقتصاص من القاتل. هذا الفعل الاخباري اتخذ طابع التسلسل الزمني والمكاني والخبري، فالخبر الصادر من معاوية وصل بعد مدة من الزمن الى شرحبيل، ثم انتقل من شرحبيل الى الجماعة التي آمنت بمعاوية ووقفت معه، وينتقل من مكان الى مكان. وهو بهذا يغير آلية نقل الخبر فبدأ الخبر بالقرطاس ثم انتقل الى العملية الثفاهية المباشرة، وهذه السلسلة من النقل الزمانيّ والمكانيّ والخبريّ، كانت المقاصد وراءها هي تكوين جماعة تؤمن بما يؤمن المتكلّم، تقبل ما يقبل وترفض ما يرفض. كلّ هذا القصد خلق تأثيراً

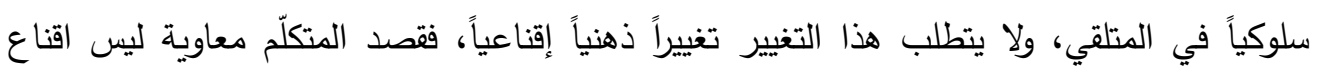
المتلقي بقضيته بقدر ايجاد صف من المؤيدين المناصرين له وبأي صورة كانت سواء ترهيبية أم اغرائية أم إقناعية. وقد صار القصد التخاطبي هنا قصداً مزدوجاً، أي قصد اخبار محتوى معين، وقصد انجاز هذا القصد نتيجة معرفة المخاطب به. 
العدد الثالث والأربعون

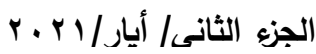

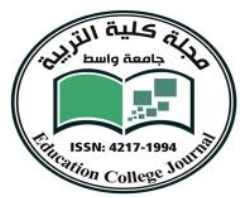

وربما يراد من الإخبار التحذير، الذي هو فعل تواصلي يراد منه أن يتواصل المخاطب مع

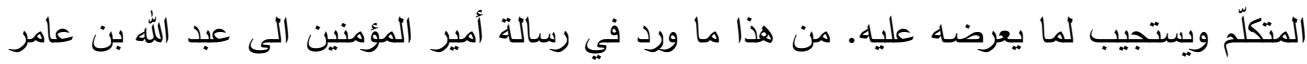
(ت10هـ)، إذ قال: "إن خير الناس عند الله عزّ وجل أقومهم لله بالطاعة فيما له وعليه وأقولهح بالحق ولو كان مراً، فإن الحق به قامت السماوات والأرض ولتكن سريرتك كعلانيتك"، (ابن مزاحم: 999 19 : • ؟) ويلتقي في فعل التحذير جانبان من جوانب التخاطب، هما الجانب التبليغيّ والجانب التهذيبيّ، فالمتكلّم يصدر تحذيره للمخاطب؛ مبلغاً إياه بالعواقب وخواتم الأمور بأسلوب أخلاقي مهذب يتأطر بالمعرفة المسبقة للمخاطب بصدق قول المتكلم "أمير المؤمنين" ليسير الفعل اللغويّ على مبدأ التصديق الذي هو من مبادئ التخاطب الأساسية، وهو المبدأ الذي يتأسس على مطابقة القول للفعل، وتصديق العمل للكلام، وقد يترتب على هذا المبدأ أن "المتكلّم متى تبيّن حقيقة قصده من قوله، أثر عنده هذا التبين نتيجتين تقوم إحداهما في تعيُّن وظيفته العملية أو قل مسؤوليته الأخلاقية، وتقوم النتيجة الثانية في صيانة قوله عن اللغو بجعله يعمل في إفادة المخاطب المعنى المقصود منه". (طه

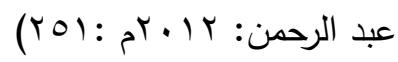
إن فعل التحذير تضمن نصحاً وارشاداً غير مبني على رغبة المخاطب وموافقته، فالمتكلّم لم ينتظر موافقة المخاطب على النصح والتحذير بل صدّر التحذير والإرشاد مباشرة من دوافع دينية أخلاقيّة، فتوحيد الباطن مع الظاهر قطع لمسارات النفاق والحقد والكره، وهي الصفات المذمومة ديناً

وخلقاً.

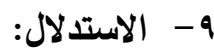

تمثل ساحة الحرب مجالاً رحباً لخلق الصراعات الكلامية والتي من صورها الرسالة، ومن

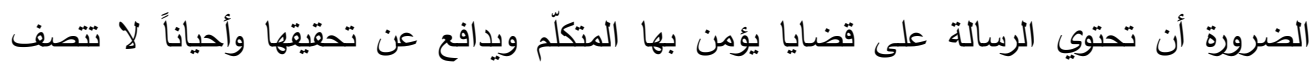
القضايا بطابع التوافق والمقبولية عند المتراسلين ممّا يحتاج المرسل عندئذ الى تأييد فحوى قضيته بأدلة غالباً ما تكون أدلة عقليّة في مثل سياقات الحروب. وينطوي الاستدلال على نشاط الانسان التأملي ليشمل العمليات الفكرية والذكاء العلمي، ويمكن عدّ أي ارتباط معرفي واع أو بديهي استدلالاً، وهو من الآليات التي اشتغل بها العلماء في التراث العربي الإسلاميّ ؛ إذ وردت " أغلب نصوصهم وخطاباتهم مبنية بناء استدلالياً معتمدين في ذلك على إنى أدوات وقواعد وضوابط عقلية، وأخرى نقليّة من أجل إقامة الحجة لاثبات قضاياهم ودعواهم، فقد راحت مختلف العلوم العربية كأصول الفقه، وعلم الكلام، والنحو، والبلاغة توظف هذه الآلية من أجل وفل ودن

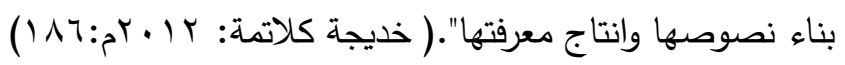


العدد الثالث والأربعون

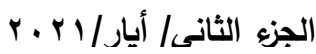

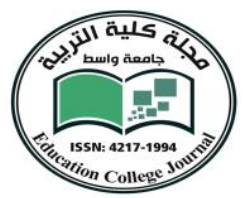

وهو أحد الأنساق التي يعتمدها الخطاب الحجاجيّ؛ لأنه انجاز تسلسلات استتتاجية، داخل الخطاب، أي متواليات من الأقوال والجمل بعضها بمثابة الحجج وبعضها الآخر بمثابة النتائج التي

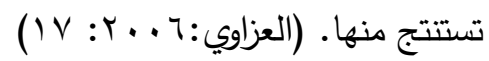

والاستدلال نسق عقلي لابدّ من حضوره في عرض الآراء والحجج، سواء كان الاستدلال عقلي منطقي أم نقليّ. ومن صور الاستدلال الحاضرة في الرسائل الحربية ما ورد في رسالة أمير المؤمنين

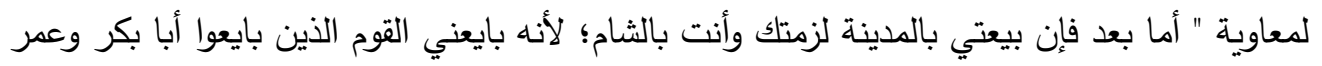
وعثمان على ما بويعوا عليه، فلم يكن للشاهد أن يختار ولا للغائب أن يرد" (ابن مزاحم: .99 19 و ( ). إن الفهم المنطقي للقضايا المعروضة في هذا النص تتشكل على صورة قياس منطقي يتلخص بالآتي: - المقدمة الأولى: بيعة أمير المؤمنين ملزمة لكل المسلمين في البلاد الإسلامية. - المقدمة الثانية: أهل الثام من المسلمين في بلاد الإسلام. - النتيجة بيعة أمير المؤمنين ملزمة لأهل الثام. هذا الاستدلال واخراج النتيجة الذي تضمنه النص السابق كان مبني على حقائق واقعية فرضت نفسها في الجغرافية السياسية الإسلامية، فبعد أن صارت كلمة المسلمين أهل الحل والعقد على مبايعة أمير المؤمنين فليس لأحد الخروج على اجماع الأمة سواء قدَّم بيعة مباشرة أم لم يقدم • إنّ الاستدلال الصادر من المرسل عن صدق قضيته، أخذ مأخذ الحجة على المرسل إليه، فلم يستطع ابطاله بأي دعوى، بل لم يستطع رده، ولكنه اعتمد أسلوباً آخر في محاولة تقليل تأثير

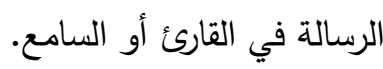

ومقاصد الاستدلال تتباين بحسب مراد المرسل وبحسب المحتوى القضوي المعروض في متن الرسالة؛ فبعد أن كان الاستدلال لتدعيم قضية المرسل والاحتجاج لها، نجد المرسل يستدل لإبطال حجة المدعي ومن ذلك ما ورد في رسالة أمير المؤمنين لمعاوية " وأما قولك أن أهل الثام هم الحكام

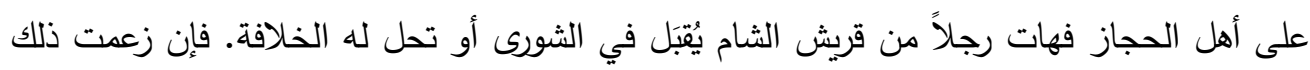
كذبّك المهاجرون والأنصار"،(ابن مزاحم: •99 1: 101)، وقد عرض المتكلّم دليله بصورة شرطية تتسجم مع ابطال حجة الآخر الذي يدعي امتلاكه حق الحكم والثرعية، والقياس الشرطيّ آلية من آليات انتاج الخطاب يعرض فيها المتكلّم قوله بطريقة السبر والتقسيم، فبدأ بعرض حجة الآخر "إن أهل الثام حكام على أهل الحجاز"، وابطالها بصيغة الثرط " فهات رجلاً من قريش"، ويوظف الثرط توظيفاً اجتماعياً سياسياً هدفه انهاء النزاع الحاصل بين الجيشين، فإن هذا القول سينتقل بصورة أو 
العدد الثالث والأربعون

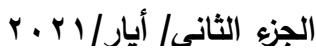

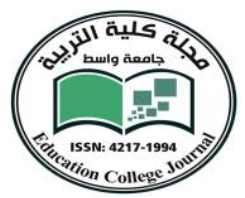

أخرى الى الجيش الأموي وستصير الحجة معروفة لاى معظم الجيش إن لم يكن كلهم، فعسى أن تصير هذه الحجة سبباً في انهاء الصراع الدائر بين الفريقين، وكما قال الثاطبي "وليس فائدة التحاكم

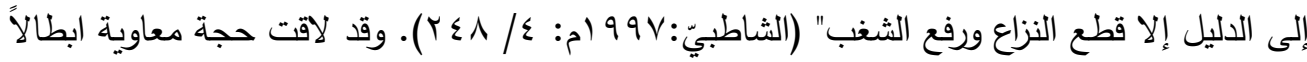
شرطياً آخر وهو" كذبك المهاجرون والأنصار" وهذا الابطال اعتمد أساساً على معرفة مسبقة بالحقائق التاريخية والاجتماعية والتي لا يستطيع أحد إنكارها أو تكذيبها، وإن كان معاوية نفسه، وقد نجح المتكلّم في اختيار دليله ممّا يعجز الخصم عن رده؛ ليصير دليلاً ناهضاً ومؤيداً لقضيته فإذا "كانت الدعوى لا بد لها من دليل، وكان الدليل عند الخصم متتازعاً فيه، فليس عنده بدليل، فصار الإتيان به عبثاً، لا يفيد فائدة ولا يحصل مقصوداً، ومقصود المناظرة رد الخصم إلى الصواب بطريق يعرفه، لأنّ رده بغير ما يعرفه من باب تكليف ما لا يطاق. فلا بدَّ من رجوعهما إلى دليل يعرفه الخصم السائل

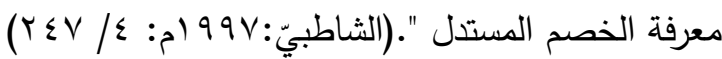
ويستدل أمير المؤمنين على أحقية مجاهدة المارقين في رسالته الى عامله مخنف ابن سليم (ت70 هـ؛ إذ قال: "سلام عليك فإني أحمد الله اليك الذي لا إله إلا هو ـ أما بعد فإن جهاد من

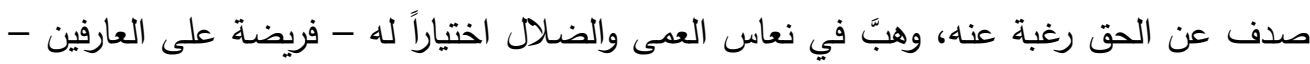

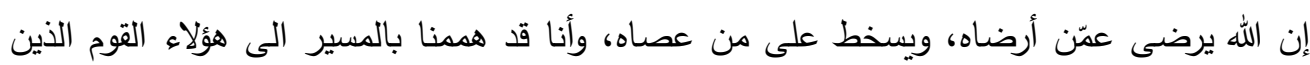
عملوا في عباد الله بغير ما أنزل الله، واستأثروا بالفيء، وعطلوا الحدود وأماتوا الحق، وأظهروا في

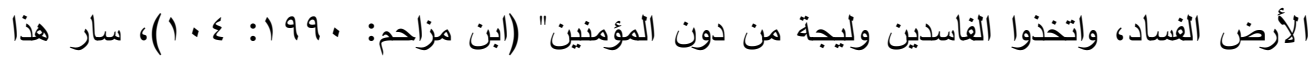
النص مساراً إقناعياً لم تقف حدوده عند المرسل إليه؛ فليس هو غاية الخطاب؛ بل وظيفة الخطاب تكوين جيش من المؤيدين لخطوات أمير المؤمنين، وهي استراتيجية قصدها أحداث تغيرات في أفكار المتلقين أو توجيهها، وتبنى عادة على "اقتراحات سابقة بشأن عناصر السياق خصوصاً المرسل اليه،

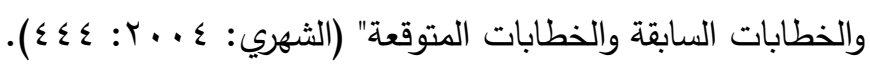

ولم تكن الحجج المعروضة في النص غائبة عن ذهن المرسل إليه أو مخالفة للواقع المعيش في حياة المسلمين. فالمسلمين لم يغب عن خلدهم أن أحق الناس للجهاد في سبيل الله هو أمير المؤمنين، وأن معاوية وجماعته كانوا أبعد الناس عن الالتزام بالأوامر والنواهي الدينية، ولم يراعوا الأموال العامة وأفندوا في أرض الله وعطلوا الحدود، كل هذا من الحقائق المعروفة لدى المتلقي، ولكن احتاج التذكير بها أو إعادة التوجيه للمعلومات على سبيل الإقناع. والمتكلّم يثبت دعواه من خلال آليات استدلاليّة غير صورية وهي الآليات الحجاجيّة؛ لما تتميز به من فعالية جدلية تخرج عن صرامة البرهان وحسابيته الآلية، من خلال أخذها بالتفاضل والتراتب، ليتان، 
العدد الثالث والأربعون

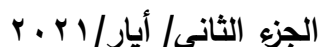

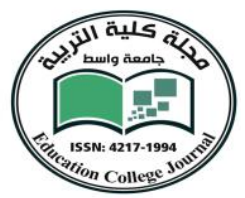

وأحياناً بالتناقض الذي لا يخرج عن حدود العقل، ولكنه يحصل بسببه الإقناع، عكس البرهان الذي قد يستوي دليله ولا يحصل معه بالضرورة اقتناع المخاطب.(طه عبد الرحمن: . . . ؟ : 1 )

\section{. 1 - استعمال المغالطة للتأثير في المتلقي:}

بالإمكان تحديد مصطلح المغالطة اللغوية بأنها: "الحجة التي تبدو في ظاهرها صحيحة، ولكنها

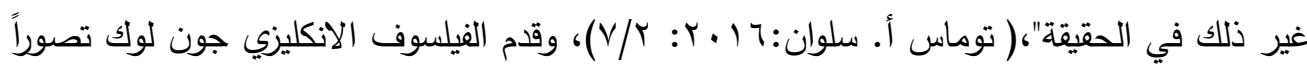
للحجج التي يستعملها المتكلم في المغالطات، فكانت على ثلاثة حجج:( توماس أ. سلوان:ج 1 ـ ب: $(1 \cdot / r$

- - حجة الالتجاء الى السلطة، ويلجأ اليها المتكلّم حينما يفقد البينة والدليل؛ لذا سميت حجة مثبتة، وحينها لا يجرؤ المتلقي على رفض هذه الحجة لما تملكه السلطة من سطوة وقسوة. - - حجة الجهل، وتتمثل هذه الحجة بعدم قدرة المتلقي برد الحجة المرعبة لا لصدقها، بل لعجزه هو ، فهو لم يجد دفاعاً ناجحاً لإثبات رايه.

- - حجة الثخصية، تتأسس على التعرض لثخصية المتلقي والهجوم على صفاته الثخصية ووسمه بصفات كالغباء، أو الخداع، أو الغش.

وقد تجلّت مسالك المغالطة واضحة للقارئ في كثير من رسائل معاوية وأصحابه، نورد منها على سبيل المثال ما ورد في كتاب معاوية الى أهل المدينة: "إن علياً قتل عثمان. والدليل على ذلك فئ فئ مكان قتلته منه، وإنما نطلب بدمه حتى يدفعوا قتلته فنقتلهم بكتاب الله، فإن دفعهم علي إلينا كففنا عنه، وجعلناها شورى بين المسلمين على ما جعلها عليه عمر بن الخطاب. وأما الخلافة فلسنا نطلبها، فأعينونا على أمرنا هذا وانهضوا من ناحيتكم"، (ابن مزاحم: .99 19 ( باج). يرتكز معاوية ابن أبي سفيان في كلامه هذا على ما يتمتع به من سلطة وسطوة بلغت ربوع الثام كافة، فيطالب بما يمتلك من هذه السلطة أهل المدينة بالوقوف معد للانتصار على علي ابن أبي طالب (عليه السلام)؛

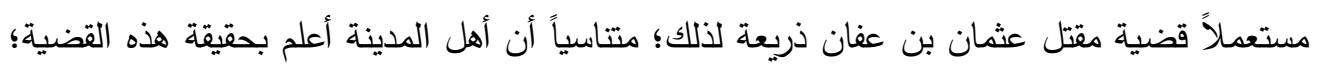
فهم عاصروا الوقعة وشاهدوها، فليس معاوية بأعرف بها منهم ولكنه حاول أن يغير قناعاتهم في سبيل انجاح مقصده، وتجييش أهل المدينة على أمير المؤمنين، وهي المغالطة التي لم تتجح وكانت مكثوفة للمتلقين، والمغالطة الأخرى الواردة هي عدم طلبه للخلافة وهي مغالطة عمد لإدراجها في رسالته لأنه فقد البينة والدليل، فهو لا يحتكم الى مبدأ البينة والدليل في تصرفاته وعلاقاته مع الآخر ، بل إن المبدأ السائد في تصرفاته وعلاقاته مع الآخر هو مبدأ السلطة والسطوة والسيطرة ، وقد 
العدد الثالث والأربعون

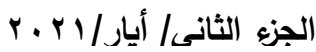

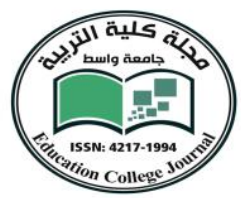

وضعهما بديلاً للاليل والبينة العقليان وهذا أساس المغالطة، " فيقع المرء في مغالطة الاحتكام الى السلطة عندما يعتقد بصدق قضية أو فكرة لا سند لها إلا سلطة قائلها" (مصطفى: ^ .. זم: 0^). ولم يكن معاوية هنا يبحث عن اقناع المتلقي بقدر عنايته برضوخه لأمره والسير في ركابه، فهو يغالط المتلقي؛ ولا يعتني بصدق المقال وكذبه؛ ويتكئ على هذه المغالطة في سبيل تحقيق "النجاح في الأغراض الجمهوريّة، ولذلك لا يشعر أنّ حدود المغالطة التي يلج عوالمها يمكن أن تتعارض مع فع ولى التصور الأخلاقيّ للشعر فالغاية تبرّز الوسيلة، وشرف الغاية بنفي كل ريبة تقترن بالمغالطة في هذا

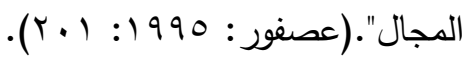
ومن هذا أيضاً ما ورد في رسالة معاوية الى عبد الله بن عمر (ت أه هـ) من قوله: "أما بعد فإنّه لم يكن أحد من قريش أحبّ إلي أن يجتمع عليه الأمة بعد قتل عثمان منك. ثم ذكرت خذلك إياه وطعنك على أنصاره فتغيرت لك، وقد هون عليّ ذلك خلافك على علي، ومحا عنك بعض ما كان منك، فأعنا-رحمك الله- على حق هذا الخليفة المظلوم".(ابن مزاحم: .999 19) (V). فقد عمد معاوية في هذه الرسالة الى ما أسماه الفيلسوف الفرنسي جون لوك "حجة الثخصية" محاولاً التأثير على هلى المرسل إليه؛ ليكسبه في جانبه في هذه المعركة، فقد ركز على قضيتين، الأولى: أن معاوية كان يرغب بأن يتسنم عبدالله بن عمر خلافة المسلمين بعد عثمان بن عفان، وهو الأمر الذي يستبطن

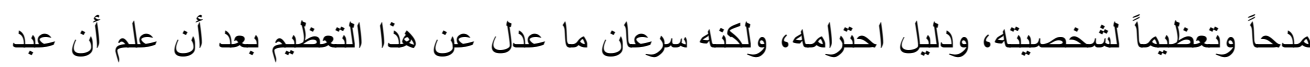
الله كان من المعارضين لسياسة عثمان في المدينة. القضية الثانية: الخلاف بين أمير المؤمنين وعبد الله بن عمر وهو خلاف لا يعدو أن يكون أكثر من سحابة صيف، الأمر الذي جعل معاوية في آخر خطابه يتوسل المعونة ويعدد الى إثارة عاطفة عبد الله بالإثارة الى مظلومية الخليفة المقتول. ونلحظ أن هذه المغالطة تركزت في الأساس على ما يكتنزه عبد الله من صفات شخصية ومكانة اجتماعية وحاول المرسل أن يستفيد من هذه المكانة بكسبه الى جانبه في خروجه على أمير المؤمنين.

وقد عمد عمرو بن العاص ( ت سـهـ) الى استعمال مغالطة مشابهة لهذه حينما بعث جواباً عن رسالة أمير المؤمنين ورد فيها: " أما بعد فإن الذي فيه صلاحنا وألفة ذات بيننا أن تتيب الى الحق، وأن تجيب الى ما تدعون إليه من شورى فصبّر الرجل منا نفسه على الحق، وعذره الناس بالمحاجزة". (ابن مزاحم: •99 1: 111) فقد حاول عمرو أن يرتدي جلباب المصلح ويتقص دور المخلص في سبيل الخروج أمام المسلمين بصورة الباحث عن صلاح الجماعة وحفظ بيضة الإسلام، فهو يجد طريقاً لصلاح الأمة ويعرضه على أمير المؤمنين لقبوله، موحياً الى السامع بأن ركون الإمام الى وحنى 
العدد الثالث والأربعون

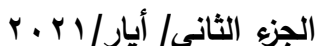

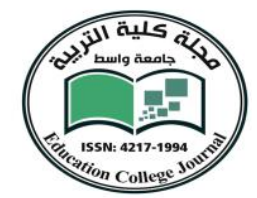

كلامه وموافقته على دعواه فيه الصلاح، وهذا القول يحمل ضمناً مغالطة كبرى تتبين من العودة الى أصل رسالة أمير المؤمنين الذي ورد فيها: " لا تجارين معاوية في باطله، فإن معاوية غمض الناس وسفه الحق" ، فمراد عمرو هو قلب جهة الحق بعد أن وصف أمير المؤمنين معاوية بالباطل فأراد أن يدخل المتلقي المسلم العادي بمتاهة المفاهيم؛ ليتساوى عنده الطرفان فلا يجد فرقاً بين نصر معاوية أو الوقوف مع أمير المؤمنين. وهنا نلحظ أنه لا يمكننا تكوين معجم لغوي للفظ المغالط؛ بل إنّ المتكلّم هو الذي يجعل كلامه ذا معنى صادقاً من حيث الظاهر، ولكننا في حال البحث عن الحقائق المستتبطة في أقوالها نجد أن القول خال من الصدق وهو في مجمله سيق من أجل التأثير في قناعات المتلقي، فلو كانت العبارات نفسها قد صدرت من شخص غير عمرو لوجب علينا البحث مرة أخرى في السياقات المصاحبة لإنتاج الكلام؛ لنجد الكلام سيق على نحو المغالطة أم على الصدق. ومن رسالة معاوية الى ابن عباس (ت1/7هـ) أنّه ورد فيها: " أما بعد فإنكم يا معشر بني هاشم

لستم الى أحد أسرع بالمساءة منكم إلى أنصار عثان بن عفان، حتى أنكم قتلتم طلحة والزبير لطلبهما دمه، واستعظامهما ما نيل منه، فإن يكن ذلك لسلطان بني أمية فقد وليها عدي وتيم، فلم

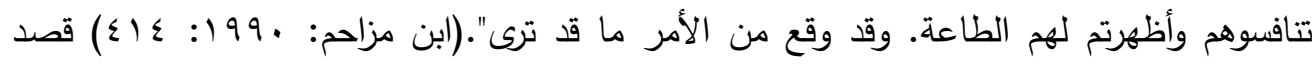
معاوية في كلامه هنا الى مغالطة سلبية وهي تحقير الخصم والتتقيص من قدراته والتثكيك في ماتي كفاءته ومصداقيته؛ فهو يتهجم عليهم لعلتين؛ الأولى: أنهم من أعداء عثمان بن عفان الخليفة الثالث، وهذا العداء "بحسب معاوية" ليس خصيصاً به وبجماعته، وقّّم حجة مغلوطة هي أنهم سكتوا حينما وليَّ الأمر قبيلة عدي وتميم، وهي إثارة لخلافة أبي بكر (ت أه)، وعمر بن الخطاب (ت أهـه)، فلما سكتم في أيام خلافتهم وأطعتم أمرهما فلم اليوم تعترضون على حكومة بني أميّة، حتى وصل هذا الاعتراض الى قتلكم طلحة والزبير لا لسبب إلا لأنهم من أنصار عثمان بن عفان. نلحظ أن هذا

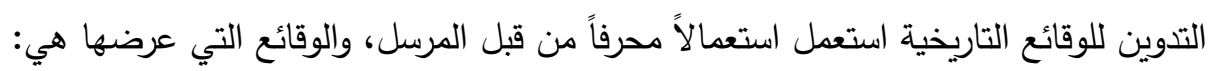

$$
\begin{aligned}
& \text { - - - الإساءة الى أنصار عثمان بن عفان. } \\
& \text { - متل طلحة والزبير . } \\
& \text { - طاعة أبي بكر وعمر بن الخطاب. }
\end{aligned}
$$

إنّ العودة الموجزة للوقائع التاريخية تكشف كثفا بيناً عن أن هذا العرض للأدلة هو عرض غايته تحريف الدليل، وهو الأمر الذي لم ينجح مع المرسل إليه؛ لما يمتلكه من معرفة بالوقائع التاريخية وبحقيقة المرسل وهذا العمل من معاوية يجعله شخصاً "يقوم بتلبيس الكذب صفة الصدق والباطل صفة الحق ... فقوام حجاجه سبل تمويهية وتغليطية الهدف منها إبطال كل ما يبتغي المجيب حفظه 
العدد الثالث والأربعون

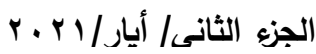

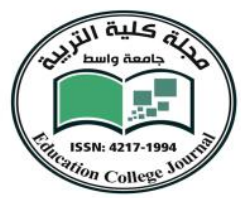

أو حفظ كلّ ما يستهدف السائل إبطاله عبر سَوق الخصم إلى الكذب والباطل، وغالباً ما يستتد في ذلك الى مسالك تقوم على التحريف والتلبيس والتعتيم والكتمان والكذب والمكر وغيرها من المسالك

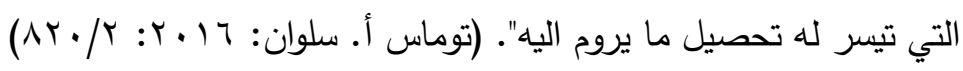
ومن رسالة معاوية الى أمير المؤمنين أنه ورد فيها: "هل لك في أمر لنا ولك فيه حياة وعذر الكر وبراءة، وصلاح للأمة، وحقن للدماء، وألفة للدين، وذهاب للضغائن والفتن أن يحكم بيننا وبينك

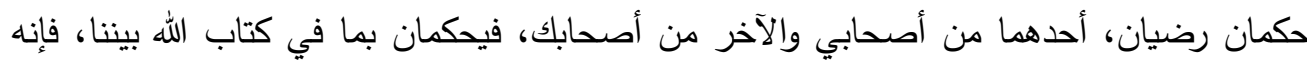
خير لي ولك، وأقطع لهذه الفتن. فاتق الله فيما دعيت لله وارضَ بحكم القرآن إن كنت من أهله.

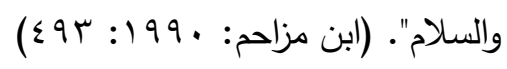

وقد مثََّّ هذا القول من معاوية المغالطة اللغويّة الكبرى التي استتبعتها مغالطة أفعالية؛ فعملية التحكيم التي حصلت بعد حين لم تكن سوى مغالطة فعلية بطلها مخادع وساذج: عمرو بن العاص المخادع الذي عرف كلَّ فنون المغالطات والخداع، وأبو موسى الأشعري المؤمن الساذج، الذي لا يجد

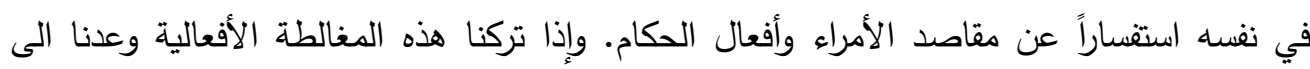
أساسها وهي المغالطة اللغويّة نجد أن معاوية استعمل فيها أسلوب الاستفهام المستبطن للرجاء، ظاهراً طيبة وإيماناً عالياً في طلبه هذا. والسامع للمرة الأولى يأخذه العجب في كلامه معتقداً بصحة إيمانه وهذا أساس المغالطة إذ يظهر المتكلّم عكس ما يستبطن، فما إن تجري الأمور بحسب ما خطط لها معاوية حتى تتكثف المقاصد المستبطنة للكلام، والتي أخفاها عن المرسل، وتتكثف حقيقة رغبته بأن يكسب الوقت؛ ليؤثر في الناس (المشاركين في القتال من كلا الطرفين)، وقد ساعده على تبني هذه الفكرة علمه بوجود من يرتجف قلبه في جيش أمير المؤمنين، علماً أنّها مغالطة مفضوحة عند المرسَل إليه؛ ولكن المرسِل نجح في التأثير في تغيير سلوك جماعة من جيش الإمام، وأصروا على الرضوخ إلى هذه الدعوة التي كانت تبعاتها ونتائجها مأساوية، فتشققت الأمة وانثق صفئ جيش الإنمام بسببها.

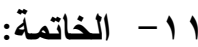

1- أسهمت الرسائل في الكشف عن معتقدات المقاتلين في المعسكرين. r-هُجمل الرسائل المسجلة في هذا الكتاب تمت بالمراسلة بين قادة الجيثين لاسيما أمير المؤمنين، ومعاوية، ونادراً ما كانت تصدر من الجنود إلى بعضهم؛ ممّا يكثف عن البنية الثقافيّة للعقليّة الإسلاميّة في ذلك الوقت، فهي عقليّة تجعل زمام الأمور والتخطيط بيد الزعيم أياً كانت النتائج، وقد شذّ عن هذه القاعدة الخوارج الذين عارضوا زعامة الإمام لأكثر من مرة. 
العدد الثالث والأربعون

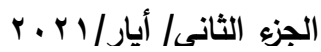

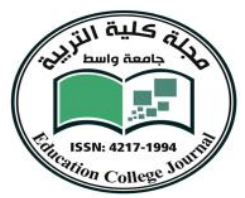

ب- لم يقف سعي أصحاب الرسائل عند التأثير في قناعات المرسل إليه، بل تعداه إلى التأثير على السامعين الذين يصلهم فحوى الرسالة.

ع-لم تتجح كثير من الرسائل في تحقيق هدفها الإقناعي؛ لتمسك المخاطبين بقناعاتهم المسبقة واصرارهم على موقفهم وغياب الرغبة الملحة في تغيير الموقف المتخذ من قبلهم سلفاً.

المصادر:

• اتجاهات البحث اللساني، ميكاإفيتش، ترجمة: الدكتورة. سعد مصلوح، الدكتور • وفاء كامل فايد، المجلس الثقافي

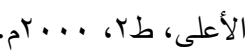

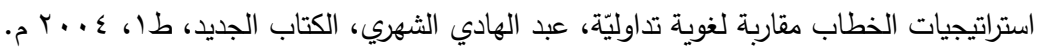

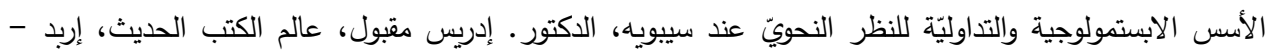

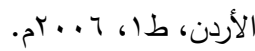

• الأصول دراسة ابستمولوجيّة للفكر العربيّ عند العرب، الدكتور . تمام حسان، دار الثؤون الثقافيّة، بغداد- العراق،

. 1911

البداية والنهاية، أبو الفداء إسماعيل بن عمر بن كثير (ت \&VVه)، المحقق: علي شيري، دار إحياء التراث العربي،

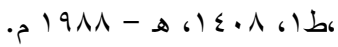

تاريخ الطبري، تاريخ الرسل والملوك ، أبو جعفر بن جرير الطبري (ت • (باهـ)، تحقيق: عحمد أبو الفضل ابراهيم، دار

المعارف، مصر ، لو 97 ام.

تاريخ اليعقبي، أحمد بن يعقوب بن وهب (ت بعد rو r هـ)، تحقيق: عبد الأمير المهنا، مؤسسة الأعلمي

لـ للمطبوعات، لبنان، د.ت.

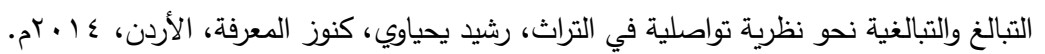

الحجاج مفهومه ومجالاته، دراسات نظرية وتطبيقية في البلاغة الجديدة، مجموعة باحثين، إعداد وتقديح: الدكتور .

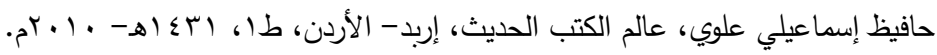

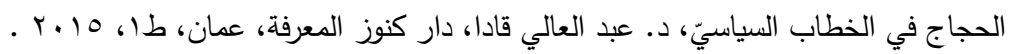

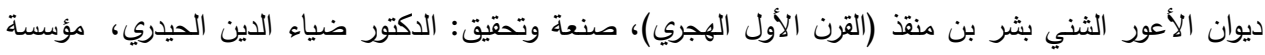

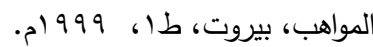

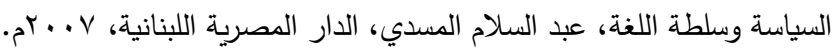

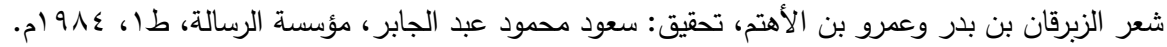

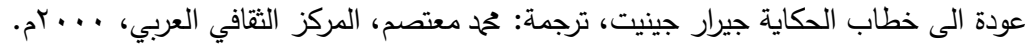

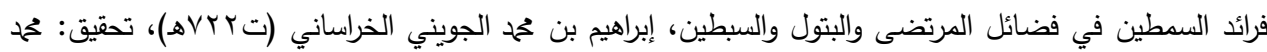

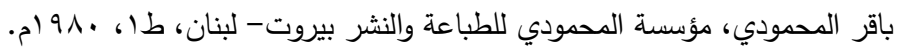

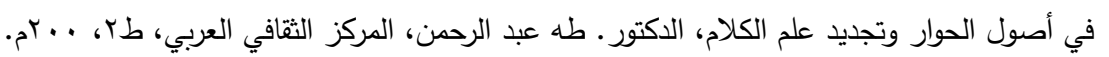

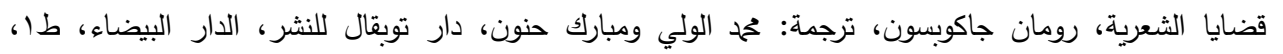


الكامل في التاريخ، على بن محمد ابن الأثير الجزري (ت.بr هـ) أبو الفذاء عبد الله القاضي، دار الكتب العلمية ،

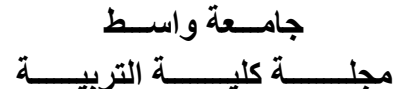

الكشاف عن غوامض التزيل وعيون الأقاويل في وجوه التأويل، جار الله الزمخشريّ (تمشهـه)، تحقيق: عادل أحمد

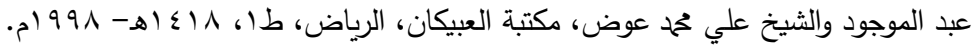

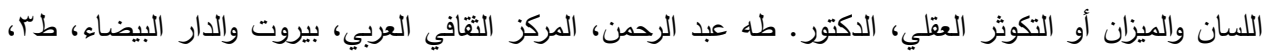

. $r \cdot 1$ r

•اللغة والحجاج، أبو بكر العزاوي، العمدة في الطبع، طا، 7 ـ . rم.

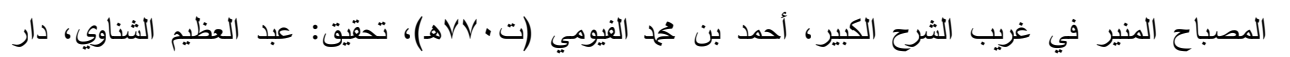

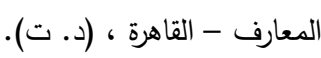

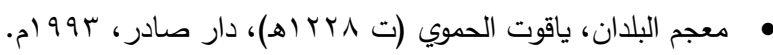

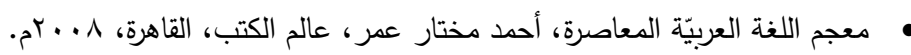

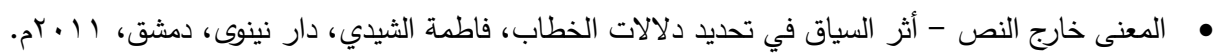

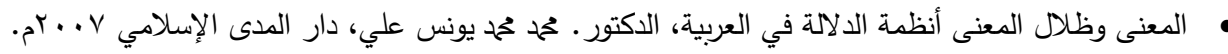

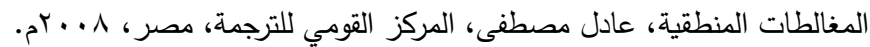

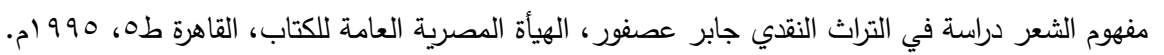

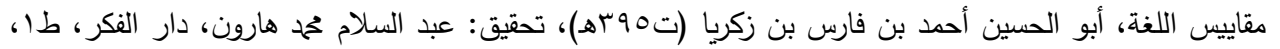

.م) $9 \vee 9-81$ - 199

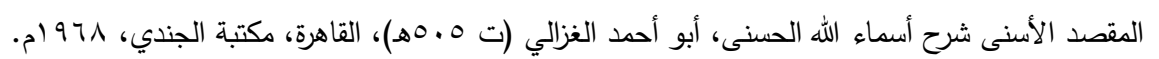

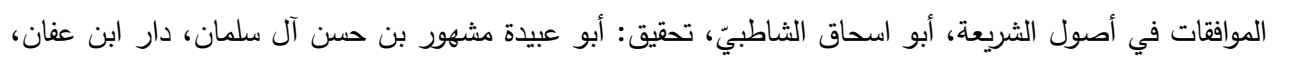
. $199 \mathrm{~V}$

موسوعة البلاغة، توماس أ. سلوان، ترجمة : نخبة من المترجمين، إشراف: عماد عبد اللطيف، المركز القومي

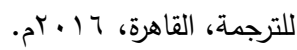
نظريّة أفعال الكلام العامة كيف ننجز الأشياء بالكلام، جون لانجشو أوستن، ترجمة: عبد القادر قنيني، دار إفريقيا

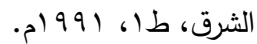

نظرية الصلة أو المناسبة سبيربر وولسون، ترجمة: هشام إبراهيم عبد الله، دار الكتاب الجديد، لبنان، 17 • بrم.

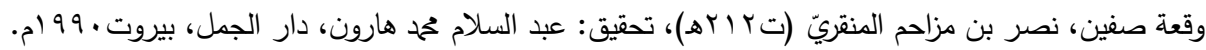

\section{البحوث المنشورة في الدوريات والمجلات:}

آليات الاستدلال الحجاجي في منهاج البلغاء وسراج الأدباء لحازم القرطاجني (بحث) خديجة كلاتمة، مجلة مخبر

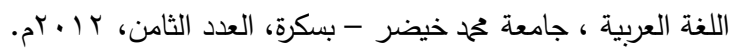

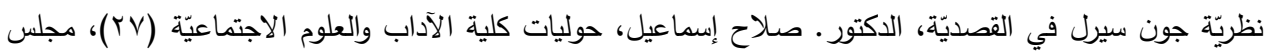

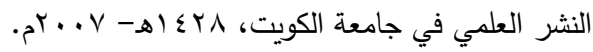

